\title{
Steam gasification of wheat straw, barley straw, willow and giganteus
}

Hansen, L.K.; Rathmann, Ole; OIsen, A.; Poulsen, K.

Publication date:

1997

Document Version

Publisher's PDF, also known as Version of record

Link back to DTU Orbit

Citation (APA):

Hansen, L. K., Rathmann, O., Olsen, A., \& Poulsen, K. (1997). Steam gasification of wheat straw, barley straw, willow and giganteus. Risø National Laboratory. Denmark. Forskningscenter Risoe. Risoe-R No. 944(EN)

\section{General rights}

Copyright and moral rights for the publications made accessible in the public portal are retained by the authors and/or other copyright owners and it is a condition of accessing publications that users recognise and abide by the legal requirements associated with these rights.

- Users may download and print one copy of any publication from the public portal for the purpose of private study or research.

- You may not further distribute the material or use it for any profit-making activity or commercial gain

- You may freely distribute the URL identifying the publication in the public portal

If you believe that this document breaches copyright please contact us providing details, and we will remove access to the work immediately and investigate your claim 


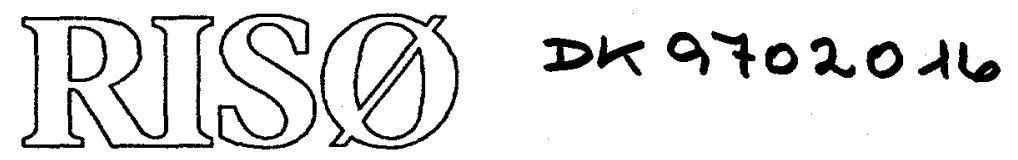

\section{Steam Gasification of Wheat Straw, Barley Straw, Willow and Giganteus}

Lars K. Hansen*, Ole Rathmann, Aksel Olsen and Karin Poulsen ${ }^{* * *}$

* Present affiliation: FLS Miljø A/S, Ramsingsvej 30, DK-2500 Valby, Denmark

** Present affiliation: ReaTech, CAT Science Centre, Frederiksborgvej 399, P.O. Box 30, DK-4000 Roskilde, Denmark

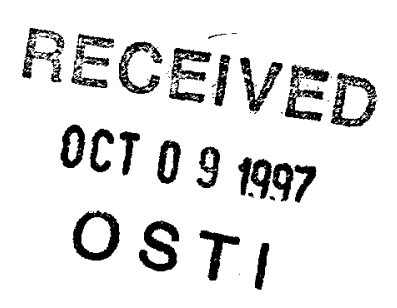

Risø National Laboratory, Roskilde, Denmark August 1997 


\section{R150-R-- $944(E N)$ \\ Steam Gasification of Wheat Straw, \\ Risø-R-944(EN) \\ Barley Straw, Willow and Giganteus}

Lars K. Hansen*, Ole Rathmann, Aksel Olsen and Karin Poulsen**

* Present affiliation: FLS Miljø A/S, Ramsingsvej 30, DK-2500 Valby, Denmark

** Present affiliation: ReaTech, CAT Science Centre, Frederiksborgvej 399, P.O. Box 30, DK-4000 Roskilde, Denmark

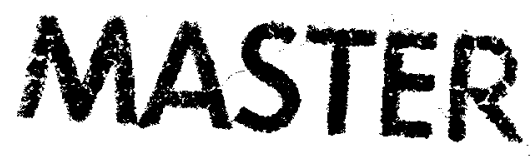

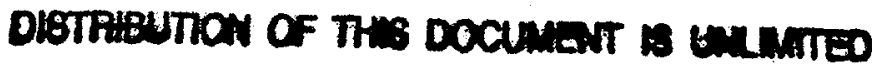

Risø National Laboratory, Roskilde, Denmark 
Abstract A thorough experimental study of the $\mathrm{H}_{2} \mathrm{O}$ gasification char-reactivity of wheat straw, barley straw, willow and giganteus at 1-10 bar total pressure, 0.15-1.5 bar $\mathrm{H}_{2} \mathrm{O}$ and 0-1.0 bar $\mathrm{H}_{2}$ and 750-925 $\mathrm{C}$, was performed in a Pressurized Thermogravimetric Analyzer. There were a total of 58 experiments.

Kinetic experiments with char of wheat straw at 10 bar total pressure showed that the reactivity increases with rising temperature and increasing partial pressure of $\mathrm{H}_{2} \mathrm{O}$, while it decreases with increasing partial pressure of $\mathrm{H}_{2}$. At constant partial $\mathrm{H}_{2} \mathrm{O}$ pressure in the absence of $\mathrm{H}_{2}$, an indication of a negative influence by the total pressure was observed.

Except for the effect of total pressure, the experimental data were analyzed by means of the Langmuir-Hinshelwood equation, including both inhibition by $\mathrm{H}_{2}$ and reactivity limitation at high $\mathrm{H}_{2} \mathrm{O}$ concentration. Also, the reactivity profile was assumed to be independent of temperature and reactant concentration. The value found for the main activation energy $E_{1}, 149 \mathrm{~kJ} / \mathrm{mole}$, describing the temperature dependence at low $\mathrm{H}_{2} \mathrm{O}$ concentration, is close to experimental values for biomass reported by other workers. At conditions relevant to both fluid-bed and entrained-flow gasifier types the present results indicate an inhibiting effect of the product gas $\mathrm{H}_{2}$, reducing the reactivity by a factor of up to 10 .

A screening study of steam gasification of barley straw, willow and giganteus in addition to the wheat straw showed reaction rates with rather equal temperature dependence. However, at equal temperatures, there was a spread in reactivity of about 10 times from the lowest (wheat and giganteus) to the highest (barley), probably due to different contents of catalytic elements.

The project has been carried out under the EFP-95 programme for the Danish Ministry of Environment and Energy and for the Danish utility associations Elsam and Elkraft.

ISBN 87-550-2247-2

ISSN 0106-2840

Information Service Department, Risø, 1997 


\section{DISCLAMIER}

Portions of this document may be illegible in electronic image products. Images are produced from the best available original document. 


\section{Contents}

1. Introduction 5

2. Experiments $\quad 6$

2.1 Experimental conditions $\quad 6$

2.2 Experimental procedure $\quad 7$

2.3 Analysis of experimental results $\quad 8$

3. Experimental results 9

3.1 Kinetic parameters for wheat straw 9

$\begin{array}{lr}3.2 \text { Influence of total pressure } & 16\end{array}$

3.3 Screening of different biomasses 17

$\begin{array}{ll}\text { 4. Conclusion } & 18\end{array}$

5. Acknowledgement 19

$\begin{array}{lr}\text { 6. References } & 20\end{array}$

7. Appendices $\quad 21$

A Modification of the Risø PTGA

B Experimental programme

C Results of individual tests

D Fuel analysis

\section{List of tables}

Table 2.1. Wheat char gasification conditions for kinetic experiments. 6

$\begin{array}{ll}\text { Table 2.2. Wheat char gasification conditions for total-pressure experiments. } & 7\end{array}$

Table 3.1. Experimental values of $\mathrm{k}_{1}$ and $\mathrm{k}_{3}$ at $750,800,850$ and $900^{\circ} \mathrm{C}$. 11

Table 3.2. Calculated values of $\mathrm{k}_{2}$ (best-fit parameters). 15

Table 3.3. Gasification of wheat, barley, willow and giganteus with $\mathrm{H}_{2} \mathrm{O} . \quad 17$ 


\section{List of figures}

Figure 2.1. Method-file containing set-points. $\quad 7$

Figure 2.2. Temperature and weight as a function of time. 8

Figure 2.3. Reactivity of wheat char at 1.5 bar $\mathrm{H}_{2} \mathrm{O}, 0$ bar $\mathrm{H}_{2}, 750^{\circ} \mathrm{C}$ and 10 bar. 9

Figure 3.1. Gasification of wheat char $0.35-1.5$ bar $\mathrm{H}_{2} \mathrm{O}, 0 \mathrm{bar} \mathrm{H}_{2}$ at $10 \mathrm{bar}$ total pressure.

Figure 3.2. Inverse reactivity for $\mathrm{H}_{2} \mathrm{O}$ gasification of wheat char. 10

$\begin{array}{ll}\text { Figure 3.3. Arrhenius plot for } \mathrm{k}_{1} \text {. } & 11\end{array}$

Figure 3.4. Arrhenius plot for $\mathrm{k}_{3}$. 12

Figure 3.5. Gasification of wheat char $0.35-1.5$ bar $\mathrm{H}_{2} \mathrm{O}, 0$ bar $\mathrm{H}_{2}, 10$ bar. Experimental data and the Langmuir-Hinshelwood law.

Figure 3.6. Gasification of wheat char 1.5 bar $\mathrm{H}_{2} \mathrm{O}, 0-1$ bar $\mathrm{H}_{2}$ and 10 bar total pressure.

The trend of the experimental data is indicated by straight lines. 14

Figure 3.7. Arrhenius plot of $\mathrm{k}_{2}$.

Figure 3.8. $\mathrm{H}_{2} \mathrm{O} / \mathrm{H}_{2}$ gasification of wheat char. Experimental data and the LangmuirHinshelwood law

Figure 3.9. Gasification of wheat char at 0.75 bar $\mathrm{H}_{2} \mathrm{O}$ partial pressure. $\quad 16$

Figure 3.10. Gasification of wheat char at 0.35 bar $\mathrm{H}_{2} \mathrm{O}$ partial pressure. $\quad 16$

Figure 3.11. Gasification reactivity of wheat char at $0.15 \mathrm{bar}_{2} \mathrm{O}$ partial pressure. $\quad 17$

Figure 3.12. Comparison of gasification reactivities of four different biomass fuels. $\quad 18$ 


\section{Introduction}

In recent years there has been an increasing interest in pressurized gasification systems due to their potentially high thermal efficiency and reduced environmental impact. The technologies include pressurized fluidized-bed gasification of biomass. In large scale the gasification is typically conducted at $800-1000^{\circ} \mathrm{C}$ and $10-20$ bar in fluid-bed gasifiers and at $1000-1800{ }^{\circ} \mathrm{C}$ and $20-40$ bar in entrained-flow gasifiers. Under these conditions the gasification reaction rate may be controlled by the chemical reaction rate. It is therefore important to know the chemical kinetics when calculating the gasification time for different fuels. The Risø Pressurized Thermogravimetric Analyser (PTGA) has been constructed to investigate gas-solid reaction under pressurized conditions. The pressure can be controlled in the range $1.5-45$ bar at maximum $1200^{\circ} \mathrm{C}$. During an experiment the weight of the solid sample is measured as a function of time and due to the well-defined conditions in the PTGA, it is very suitable for measuring chemical reactivity. For these kinds of measurements the experimental conditions are chosen so as to ensure constant partial pressures and temperature throughout the entire particle. A thorough description of the PTGA was given by Rathmann (1995). In order to perform measurements under $\mathrm{H}_{2} \mathrm{O}$ gasification conditions the flow system of the PTGA was modified slightly as described in Appendix A. By use of the PTGA it is possible to make a systematic test of the influence of different parameters on the chemical reactivity.

It is generally accepted that the reaction of char $\mathrm{CO}_{2}$ follows a rate law of the Langmuir-Hinshelwood type (Reif, 1952, Alfons and Schoeters, 1985):

$$
F\left(P_{\mathrm{CO}_{2}}, P_{\mathrm{CO}}, T\right)=\frac{k_{1} P_{\mathrm{CO}_{2}}}{1+k_{2} P_{\mathrm{CO}}+k_{3} P_{\mathrm{CO}_{2}}}
$$

$\mathrm{k}_{1}, \mathrm{k}_{2}$ and $\mathrm{k}_{3}$ are reaction rate constants, $\mathrm{PCO}_{2}$ and $\mathrm{PCO}$ are the partial pressures of $\mathrm{CO}_{2}$ and $\mathrm{CO}$, respectively. This complex rate expression can describe both reactivity limitation at high reactant concentration $\left(\mathrm{k}_{3}\right)$ and inhibition by the product gas $\left(\mathrm{k}_{2}\right)$.

In several works $\mathrm{CO}_{2}$ gasification of coal in PTGA have been studied as well as biomass. The range of the activation energy $\left(E_{1}\right)$ from 10 different works was found to be between 100 and $193 \mathrm{~kJ} /$ mole and with an average value of $157 \mathrm{~kJ} / \mathrm{mole}$ (Gjernes et al., 1995). Illerup and Rathmann, 1996 found an activation energy of $152 \mathrm{~kJ} / \mathrm{mole}$ for wheat straw.

In the present work a thorough investigation of the $\mathrm{H}_{2} \mathrm{O}$ gasification kinetics of wheat straw is given, using a similar Langmuir-Hinshelwood rate law equation.

$$
F\left(P_{\mathrm{H}_{2} \mathrm{O}}, P_{\mathrm{H}_{2}}, T\right)=\frac{k_{1} P_{\mathrm{H}_{2} \mathrm{O}}}{1+k_{2} P_{\mathrm{H}_{2}}+k_{3} P_{\mathrm{H}_{2} \mathrm{O}}}
$$

The experiments were carried out at 10 bar and at $650-925^{\circ} \mathrm{C}$. The pulverized straw has been pyrolyzed in the Risø Pressurized Entrained-flow Reactor (PEFR) at 15 bar and $900^{\circ} \mathrm{C}$. The PEFR is described by Hansen et. al. (1995). The influence of the gasification pressure in the PTGA was tested in the range 1-10 bar. Screening tests with barley straw, willow and giganteus have been conducted at 10 bar. 


\section{Experiments}

\subsection{Experimental conditions}

The experiments have been carried out in the pressurized thermogravimetric analyzer with four different biomasses prepyrolyzed in the pressurized entrained-flow reactor (PEFR) at Risø.

\section{Kinetics:}

The wheat straw sample, used for the kinetic experiments, consisted of straw ground to a particle size $<150 \mu \mathrm{m}$ and pyrolyzed in the PEFR at $900^{\circ} \mathrm{C}$ and 15 bar. The experimental conditions in Table 2.1 were chosen in order to determine the kinetic parameters given in equations 2.1 and 2.2. The rate of reaction, $F\left(P_{\text {reactant }}, P_{\text {product }}, T\right)$, is expressed by the Langmuir-Hinshelwood expression:

$$
F\left(P_{H_{2} \mathrm{O}}, P_{H_{2}}, T\right)=\frac{k_{1} P_{H_{2} \mathrm{O}}}{1+k_{2} P_{\mathrm{H}_{2}}+k_{3} P_{\mathrm{H}_{2} \mathrm{O}}}
$$

The rate constants are described by an Arrhenius equation:

$$
k_{i}=k_{0 i} e^{\frac{-E_{a i}}{R T}}
$$

In the present work 24 kinetic experiments have been carried out (Appendix B). The temperature range was chosen so as to obtain a rate of reaction controlled by the chemical reaction and a time for complete conversion that was not too long. The partial pressures of the reactant and product gases in Table 2.1 were chosen to cover the range of interest for industrial gasifiers as well as possible. The experiments in the PTGA have been carried out at $10 \mathrm{bar}$ and with a gas flow of $4-6 \mathrm{~N} /$ /minute corresponding to a superficial velocity of $2-3 \mathrm{~cm} / \mathrm{s}$ in the reaction chamber.

Table 2.1. Wheat char gasification conditions for kinetic experiments.

\begin{tabular}{lrc}
\hline Particle size & $<150$ & $\mu \mathrm{m}$ \\
Pyrolysis temperature & 900 & ${ }^{\circ} \mathrm{C}$ \\
Pyrolysis pressure & 15 & bar \\
Pyrolysis time & $2-3$ & $\mathrm{~s}$ \\
Gasification temperature & $750-925$ & ${ }^{\circ} \mathrm{C}$ \\
Gasification pressure & 10 & bar \\
Partial pressure of $\mathrm{H}_{2} \mathrm{O}$ & $0.35-1.5$ & bar \\
Partial pressure of $\mathrm{H}_{2}$ & $0-1.5$ & bar \\
\hline
\end{tabular}

The influence of the total pressure has been investigated under the conclitions listed in Table 2.2. 
Table 2.2. Wheat char gasification conditions for total-pressure experiments.

\begin{tabular}{lrl}
\hline Particle size & $<150$ & $\mu \mathrm{m}$ \\
Pyrolysis temperature & 900 & ${ }^{\circ} \mathrm{C}$ \\
Pyrolysis pressure & 15 & bar \\
Pyrolysis time & $2-3$ & $\mathrm{~s}$ \\
Gasification temperature & $750-900$ & ${ }^{\circ} \mathrm{C}$ \\
Gasification pressure & $1-10$ & bar \\
Partial pressure of $\mathrm{H}_{2} \mathrm{O}$ & $0.15-0.75$ & bar \\
\hline
\end{tabular}

\subsection{Experimental procedure}

Approximately $7 \mathrm{mg}$ of the fuel sample was placed on the sample tray, the pressure vessel was closed and the vessel pressurized. All gas lines carrying steam containing gases were kept at $250-290^{\circ} \mathrm{C}$, a temperature well above the water boiling point at the experimental pressure. In advance of the actual experiment the steam generator was producing steam at the chosen experimental conditions (rate and pressure) to a pressurized bypass line in order to give a steam flow rate variation as small as possible at the moment when the steam was switched on to the test gas inlet line.

The sample was heated to $150^{\circ} \mathrm{C}$ in $\mathrm{N}_{2}$ for 15 minutes and the weight of the dry sample was measured. After drying the temperature was raised to the reaction temperature and the sample was kept at this temperature for about 5 minutes before the steam and hydrogen were supplied. By the end of each experiment, the temperature was raised to $1000^{\circ} \mathrm{C}$ to force complete conversion in order to measure the ash weight. An example of a method-file containing the set points are given in Figure 2.1. Figure 2.2 shows the temperature and weight as a function of time for a typical experiment.

\begin{tabular}{|c|c|c|c|c|c|c|c|}
\hline \multicolumn{8}{|c|}{ 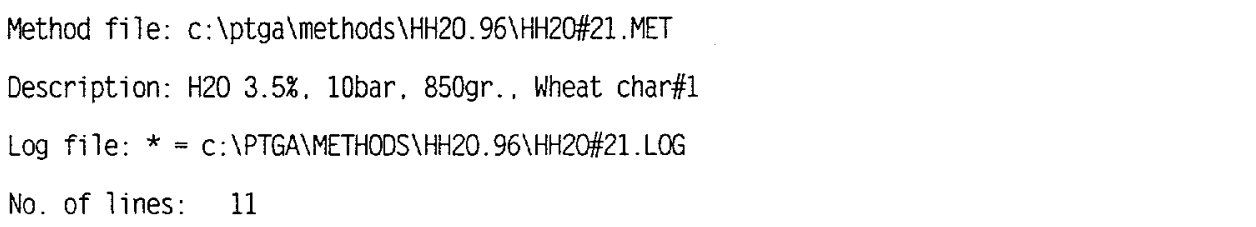 } \\
\hline line \# & Dur.min & Rate $\mathrm{d} / \mathrm{m}$ & Temp. & stat & RFlow & DFTow & Press \\
\hline 1 & 2 & 0 & 26 & 1 & 500 & 100 & 10 \\
\hline 2 & 1 & 0 & 200 & 1 & 500 & 100 & 10 \\
\hline 3 & 15 & 0 & 200 & 1 & 2000 & 300 & 10 \\
\hline 4 & 20 & 0 & 200 & 1 & 5700 & 1200 & 10 \\
\hline 5 & 21.67 & 30 & 850 & 1 & 5700 & 1200 & 10 \\
\hline 6 & 15 & 0 & 850 & 1 & 5500 & 1200 & 10 \\
\hline 7 & 90 & 0 & 850 & 3 & 5500 & 1200 & 10 \\
\hline 8 & 5 & 30 & 1000 & 3 & 5500 & 1200 & 10 \\
\hline 9 & 7 & 0 & 1000 & 3 & 5500 & 1200 & 10 \\
\hline 10 & 5 & 0 & 800 & 1 & 5700 & 1200 & 10 \\
\hline 11 & 30 & 0 & 20 & 1 & 2000 & 300 & 10 \\
\hline Total & 211.67 & & & & & & \\
\hline
\end{tabular}

Figure 2.1. Method-file containing set-points. 


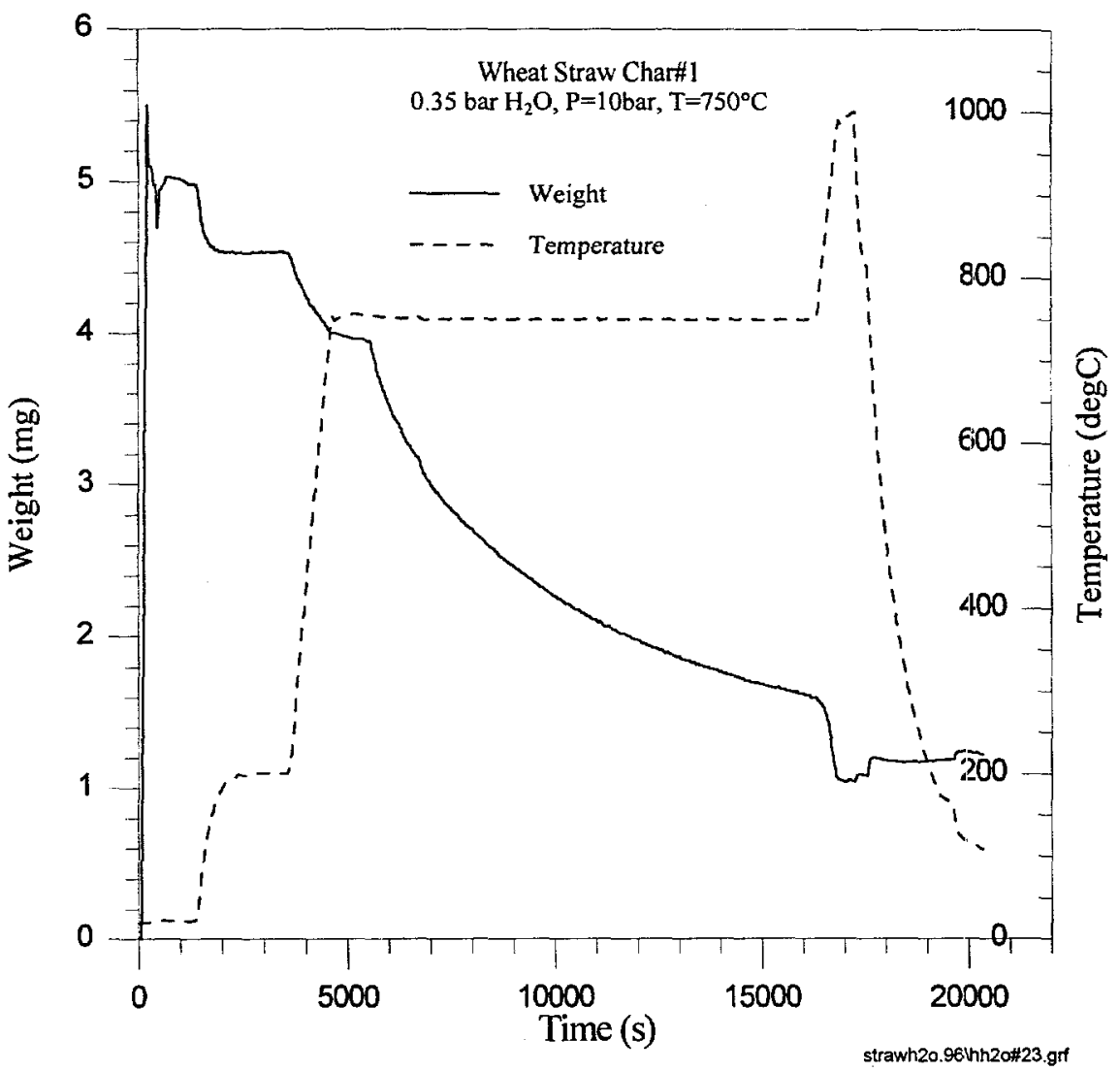

Figure 2.2. Temperature and weight as a function of time.

\subsection{Analysis of experimental results}

The weight signal was converted from millivolt to milligram and compensated for the effect of thermal expansion of the balance arm of the PTGA and of the buoyancy (Rathmann, 1995). A special program was used in order to calculate the conversion and reactivity based on equations 2.3 and 2.4 , respectively.

$$
\begin{array}{r}
X=1-\frac{m-m_{a s h}}{m_{0}-m_{a s h}} \\
R_{n}=-\left(\frac{1}{m-m_{a s h}}\right) \frac{d m}{d t}
\end{array}
$$

where $m$ is the mass as a function of time, $t$ is the time, $m_{0}$ is the mass of the sample at the beginning of an experiment and $m_{\text {ash }}$ is the mass of the ash in the sample. The derivative in the right-hand side of equation 2.4 was found by a numerical scheme, which also included averaging over a number of subsequent single measurements for the purpose of noise rejection.

The average value of the observed reaction rate was preferably calculated over the conversion range of $40-60 \%$ for use in the further analysis. Figure 2.3 gives an example of a reactivity plot. With the presence of $\mathrm{H}_{2}$ in the experiments this averaging range had to be displaced to higher conversion values due to a longer dead time in the $\mathrm{H}_{2}$ line compared to the steam line. 


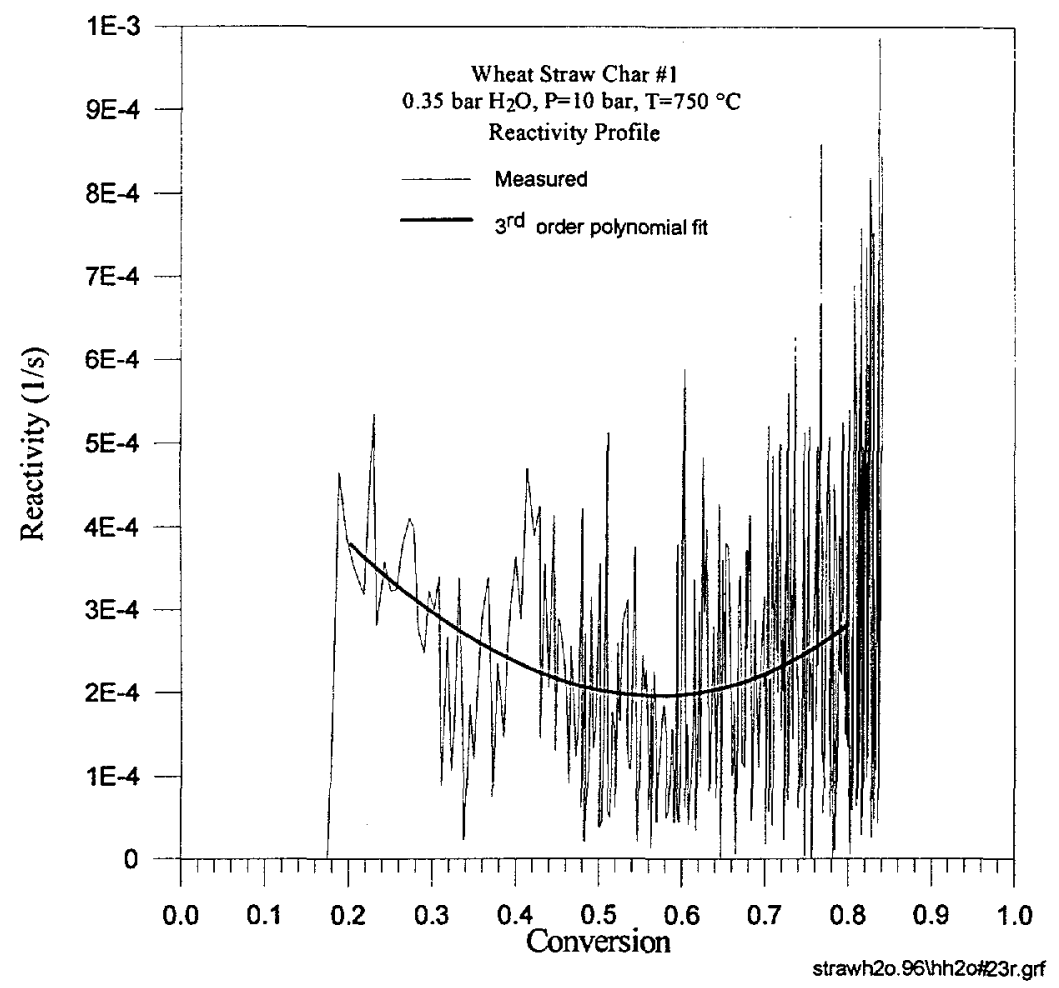

Figure 2.3. Reactivity of wheat char at $1.5 \mathrm{bar} \mathrm{H}_{2} \mathrm{O}, \mathrm{O}$ bar $\mathrm{H}_{2}, 750^{\circ} \mathrm{C}$ and $10 \mathrm{bar}$.

The reactivity program also calculated the maximum rate of diffusion of reactant gas to the particles in order to ensure that the reaction was truly based on the kinetic reactivity and not limited by diffusion. The ratio between maximum diffusion rate and reactivity was always in the range 10-1000. Thus, the reaction rate was always safely within the kinetic regime.

\section{Experimental results}

This chapter describes the $\mathrm{H}_{2} \mathrm{O}$ gasification of biomass char carried out with gases containing $\mathrm{H}_{2} \mathrm{O}, \mathrm{H}_{2}$ and $\mathrm{N}_{2}$. In section 3.1 the kinetic parameters for $\mathrm{H}_{2} \mathrm{O}$ gasification of wheat straw are derived according to equation 2.1. In section 3.2 the influence of total pressure on the reactivity of wheat straw is described. The results of comparing the reactivities of wheat, barley, willow and giganteus are reported in section 3.3.

\subsection{Kinetic parameters for wheat straw}

The experiments were carried out under the experimental conditions given in Appendix B. Figure 3.1 shows the reactivity as a function of the temperature for the experiments carried out with different pressures of $\mathrm{H}_{2} \mathrm{O}$ in the absence of $\mathrm{H}_{2}$ and a total pressure of 10 bar. As expected the reactivity increases with increasing temperature and increasing partial pressure of $\mathrm{H}_{2} \mathrm{O}$. However, the effect of reactivity limitation at high $\mathrm{H}_{2} \mathrm{O}$ concentration is visible in the whole $\mathrm{H}_{2} \mathrm{O}$ range as the reactivity increases less than in proportion to the partial pressure. 


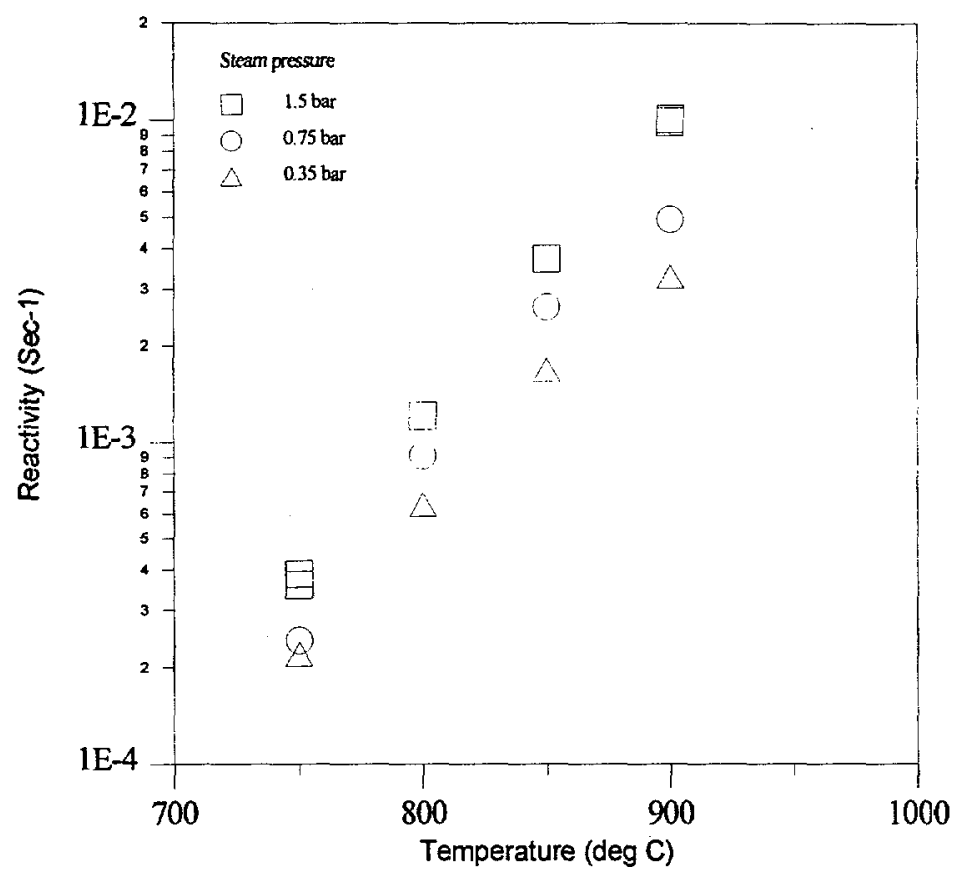

Figure 3.1. Gasification of wheat char $0.35-1.5$ bar $\mathrm{H}_{2} \mathrm{O}, \mathrm{O}$ bar $\mathrm{H}_{2}$ at 10 bar total pressure.

Equation 3.1. shows that on plotting $1 / \mathrm{R}_{\mathrm{n}}$ as a function of $1 / \mathrm{PH}_{2} \mathrm{O}$ at equal temperatures, $k_{1}$ and $k_{3}$ can be found from the slope and the $Y$-axis interception of a fitting line. This is illustrated in Figure 3.2 showing the graphs for $750,800,850$ and $900^{\circ} \mathrm{C}$. It is seen that straight lines give a good representation of the experimental results, which means that the relation between the rate of reaction and the $\mathrm{H}_{2} \mathrm{O}$ partial pressure can be described by equation 3.1 when the partial pressure of $\mathrm{H}_{2}$ is zero.

$$
R_{n}=\frac{k_{1} P_{H_{2} \mathrm{O}}}{1+k_{3} P_{\mathrm{H}_{2} \mathrm{O}}} \quad \Leftrightarrow \quad \frac{1}{R_{n}}=\frac{1}{k_{1}} \cdot \frac{1}{P_{\mathrm{H}_{2} \mathrm{O}}}+\frac{k_{3}}{k_{1}}
$$

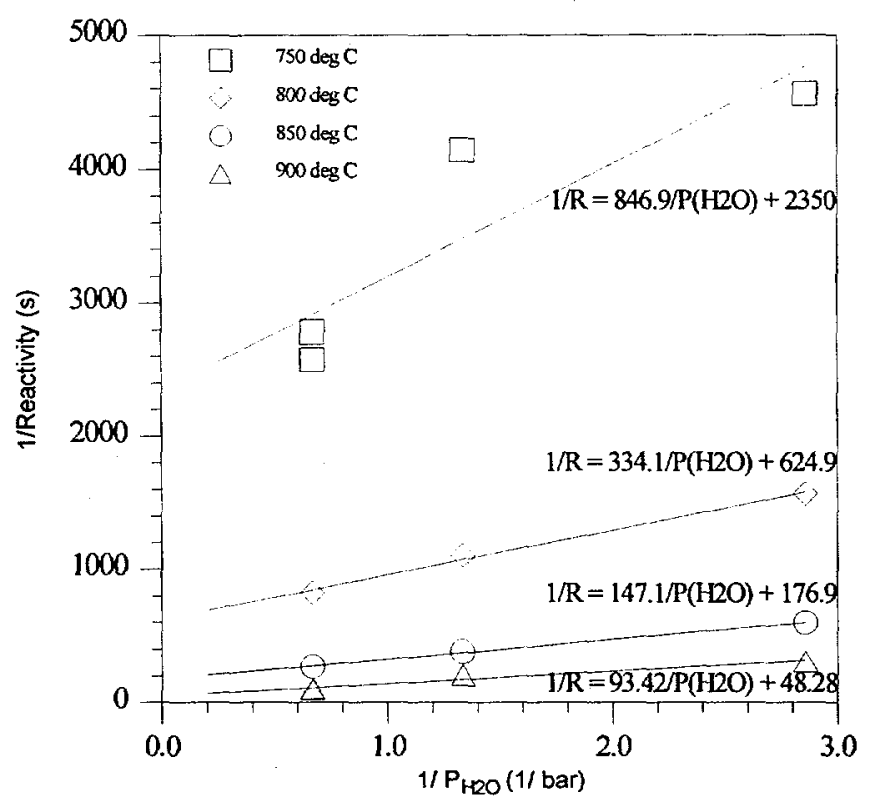

Figure 3.2. Inverse reactivity for $\mathrm{H}_{2} \mathrm{O}$ gasification of wheat char. 
The temperature dependence of $k_{1}$ and $k_{3}$ is found from Figure 3.2 and is listed in Table 3.1.

Table 3.1. Experimental values of $k_{1}$ and $k_{3}$ at $750,800,850$ and $900^{\circ} \mathrm{C}$.

\begin{tabular}{cccc}
\hline Temperature $\left({ }^{\circ} \mathrm{C}\right)$ & $1 / \mathrm{T}(1 / \mathrm{K})$ & $\mathrm{k}_{1}(1 / \mathrm{s}$ bar $)$ & $\mathrm{k}_{3}(1 / \mathrm{bar})$ \\
\hline 750 & 0.0009775 & 0.000118 & 2.775 \\
800 & 0.0009320 & 0.002993 & 1.870 \\
850 & 0.0008905 & 0.006798 & 1.203 \\
900 & 0.0008525 & 0.010704 & 0.517 \\
\hline
\end{tabular}

From Figures 3.3 and 3.4 it is seen that the Arrhenius equation (2.2) describes the temperature dependency quite well for both $k_{1}$ and $k_{3}$. The actual Arrhenius expressions with best-fit pre-exponential factors and activation energies are given in equations (3.2) and (3.3).

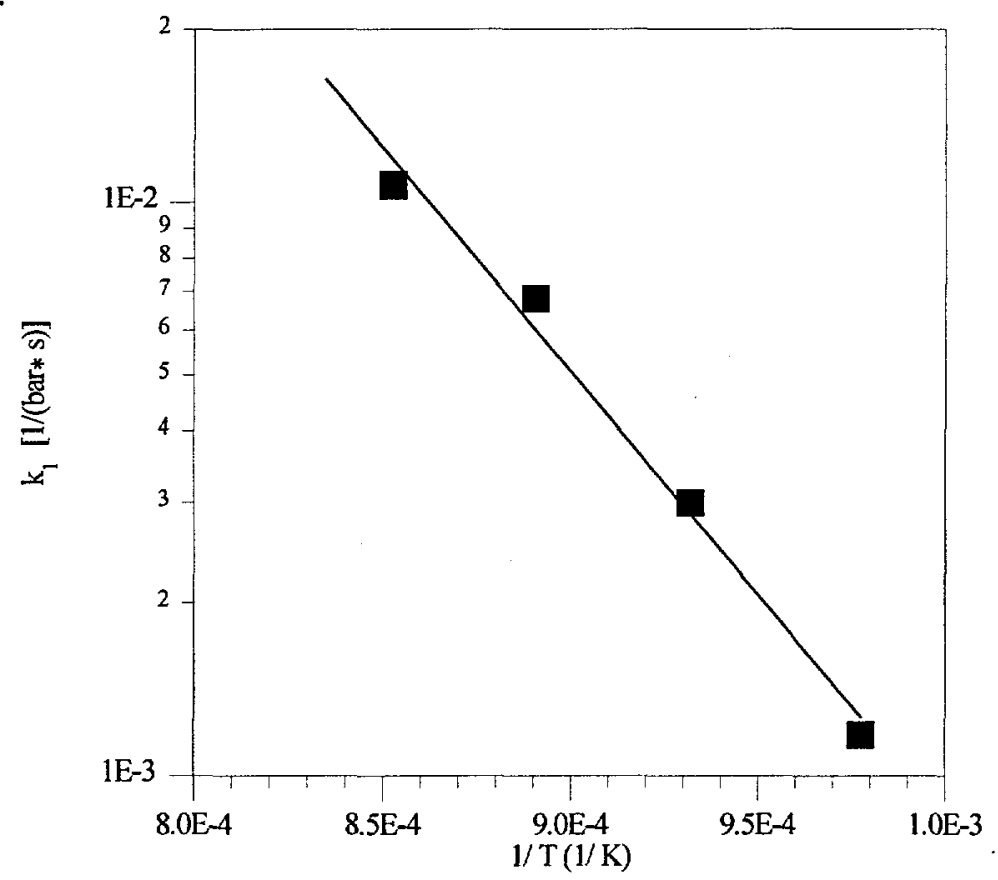

Figure 3.3. Arrhenius plot for $k_{l}$. 


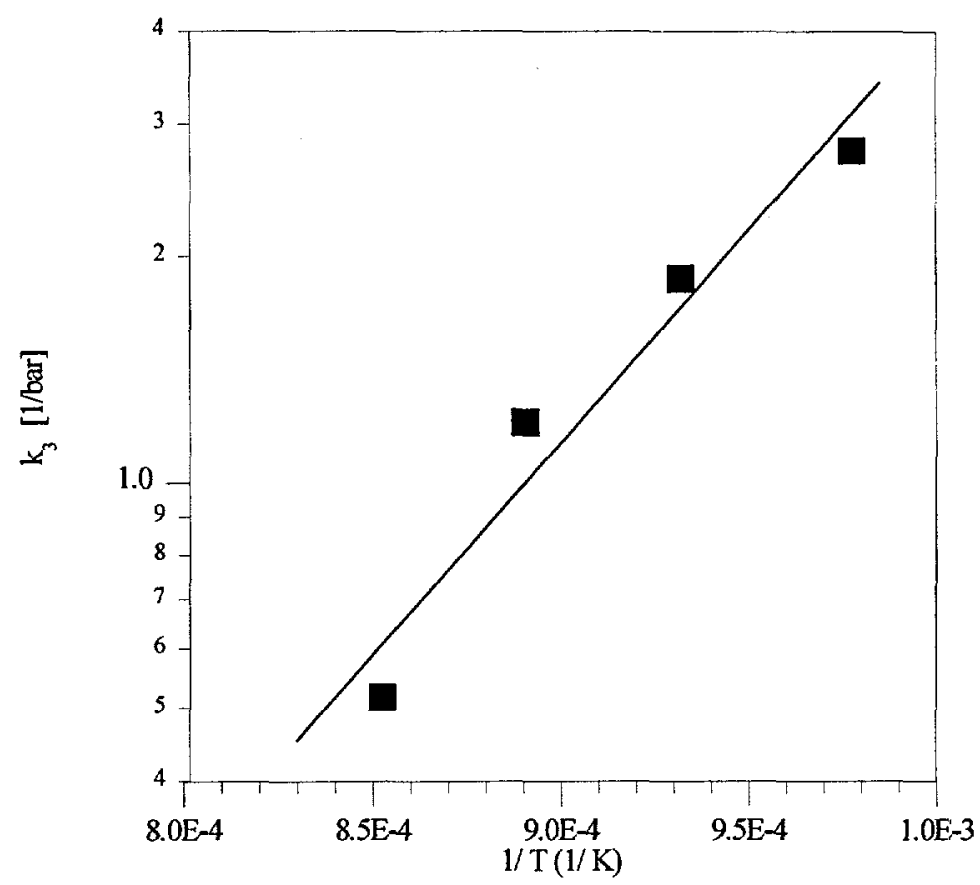

Figure 3.4. Arrhenius plot for $k_{3}$.

$$
\begin{aligned}
& k_{1}=51.3 \cdot 10^{3} \cdot e^{\frac{-149 \cdot 10^{3}}{R T}} \\
& k_{3}=9.10 \cdot 10^{-6} \cdot e^{\frac{+108 \cdot 10^{3}}{R T}}
\end{aligned}
$$

The activation energy for $\mathrm{k}_{1}$ is found to be $149 \mathrm{~kJ} / \mathrm{mole}$ while the pseudo-activation energy associated with $\mathrm{k}_{3}$ is found to be negative $(-108 \mathrm{~kJ} / \mathrm{mole})$. This reflects the fact that the limitation effect decreases with increasing temperature and that the effect is negligible at high temperatures. In figure 3.5 it is shown that, using the deduced expressions for $\mathrm{k}_{1}$ and $\mathrm{k}_{2}$, the experimental reactivity data are well represented by the Langmuir-Hinshelwood law. 


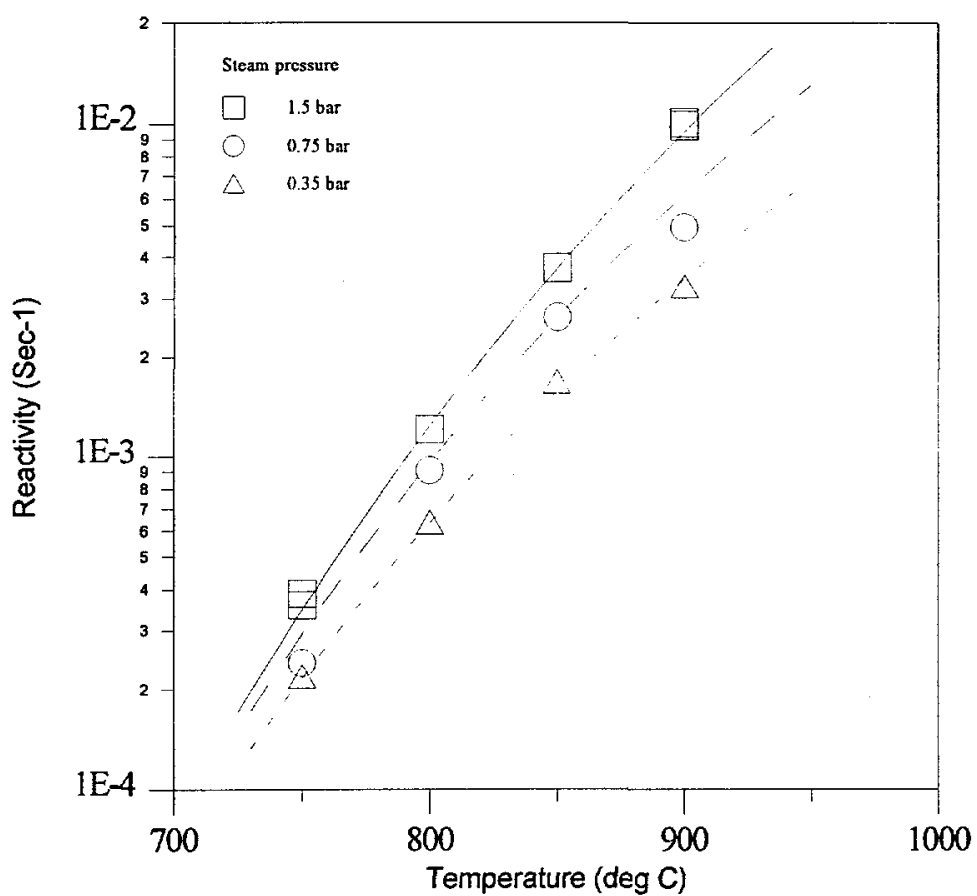

Figure 3.5. Gasification of wheat char 0.35-1.5 bar $\mathrm{H}_{2} \mathrm{O}, \mathrm{O}$ bar $\mathrm{H}_{2}, 10$ bar. Experimental data and the Langmuir-Hinshelwood law.

The above results may be compared with the results reported by Moilanen et al. (1993) for steam gasification of peat and brown coal. Assuming the gasification to be a $1^{\text {st }}$ order process, they found activation energies ranging from 194 to $267 \mathrm{~kJ} / \mathrm{mole}$. Consequently, their activation energies include to some extent also the effect of reactivity limitation. Depending on whether far from or close to reactivity limitation, the corresponding 1st order activation energy of the present study would be a value somewhere between $\mathrm{E}_{1}=$ $149 \mathrm{~kJ} / \mathrm{mole}$ and $\mathrm{E}_{1}-\mathrm{E}_{3}=257 \mathrm{~kJ} / \mathrm{mole}$, and actually this range overlap well with the results of Moilanen et al. The present activation energy is also close to the value of 152 $\mathrm{kJ} /$ mole found by Illerup and Rathmann (1996) for $\mathrm{CO}_{2}$ gasification.

For coal, activation energies from 188 to $272 \mathrm{~kJ} /$ mole can be found in the review by Laurendeau (1978), while a more recent study by Mühlen et al. (1985) reports a value of $154 \mathrm{~kJ} /$ mole. Mühlen also reports the corresponding activation energy for $\mathrm{CO}_{2}$ gasification, $153 \mathrm{~kJ} / \mathrm{mole}$, very close to that. Thus the activation energy for steam gasification of biomass char seems to be a little lower than for coal char. This may possibly be due to the higher content of catalysts in biomass (alkali metals), the effect of which is reduced with increasing temperature.

Figure 3.6 shows the reactivity for the experiments carried out with a mixture of 1.5 bar $\mathrm{H}_{2} \mathrm{O}$ and $0,0.5$ and 1.0 bar $\mathrm{H}_{2}$. When the reactant gas contains $\mathrm{H}_{2}$ the rate of reaction is much slower than that for a gas containing only $\mathrm{H}_{2} \mathrm{O}$. The experiments are therefore carried out at a higher temperature level $800-925^{\circ} \mathrm{C}$ in order to obtain reasonable reaction rates. 


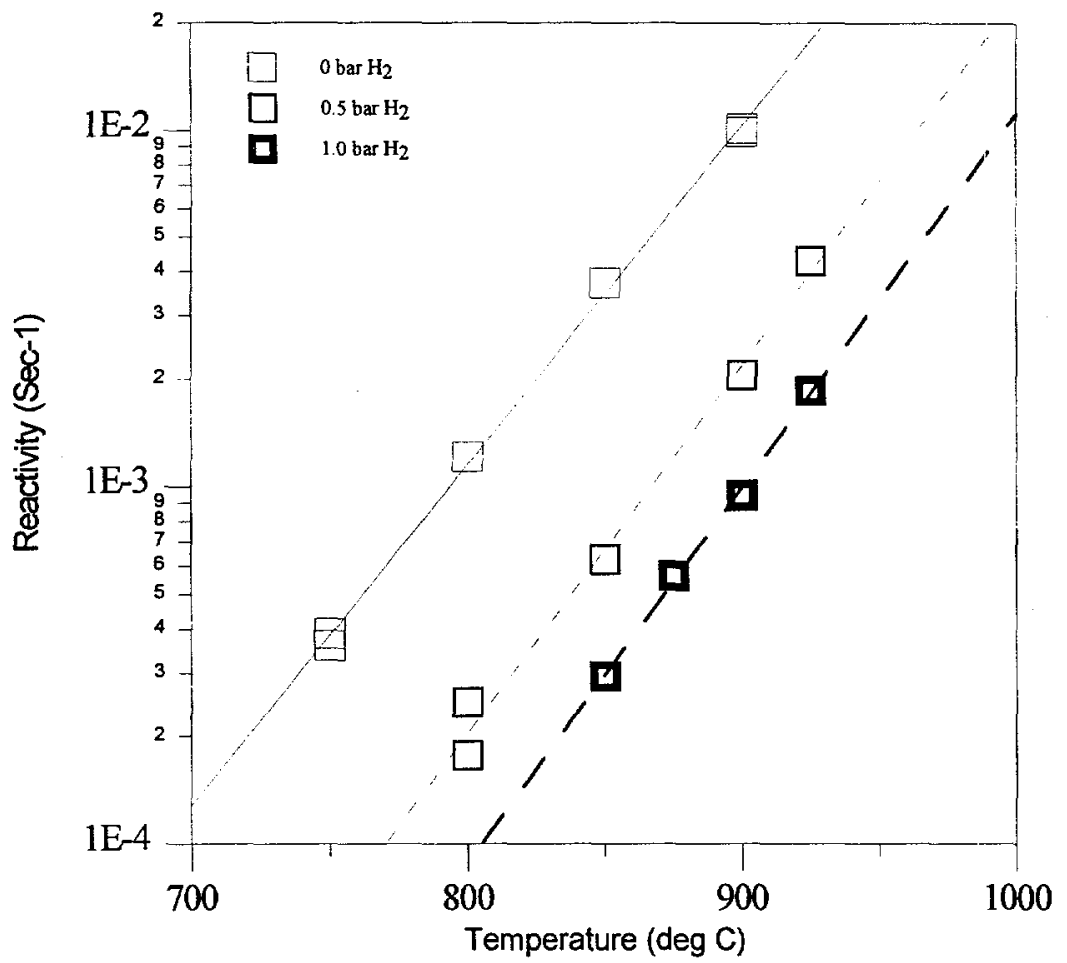

Figure 3.6. Gasification of wheat char 1.5 bar $\mathrm{H}_{2} \mathrm{O}, 0-1$ bar $\mathrm{H}_{2}$ and 10 bar total pressure. The trend of the experimental data is indicated by straight lines.

From the experiments shown in Figure $3.6, \mathrm{k}_{2}$ can be deduced by means of equation 1.2 for 800,850 and $900^{\circ} \mathrm{C}$ using the values for $\mathrm{k}_{1}$ and $\mathrm{k}_{3}$ found from equations 3.2 and 3.3, as shown in Figure 3.7.

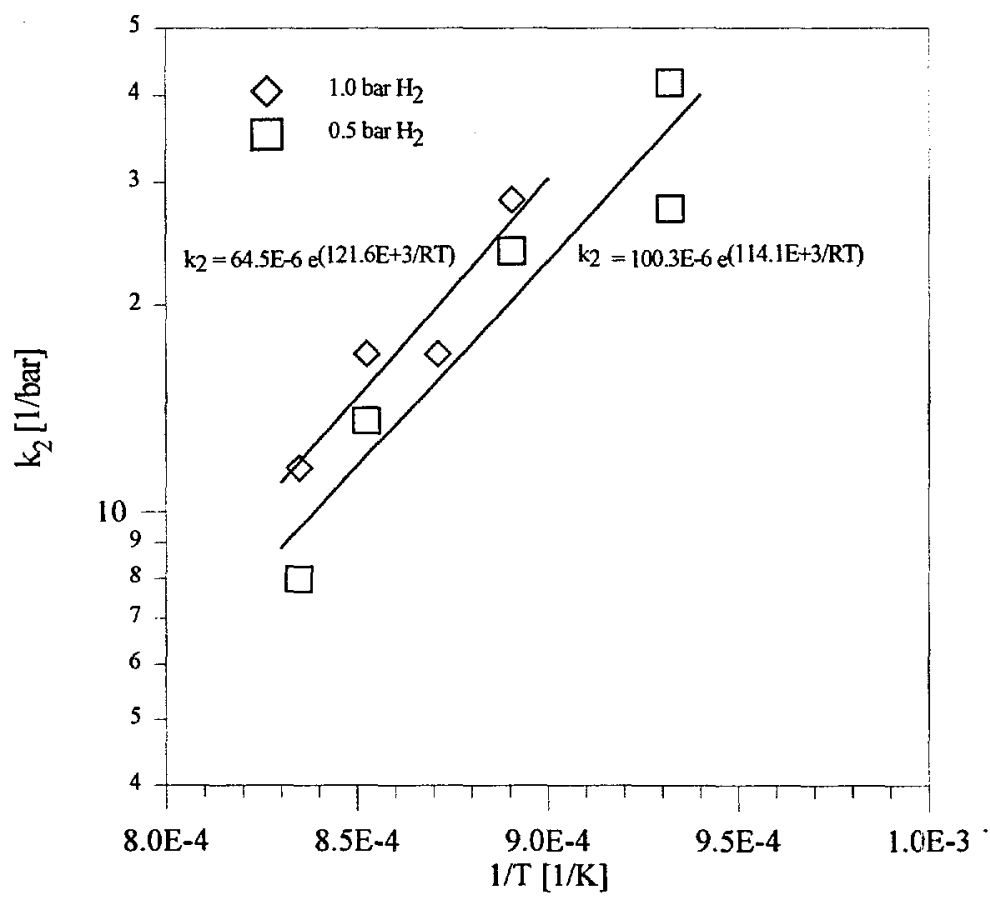

Figure 3.7. Arrhenius plot of $k_{2}$.

Despite the large uncertainty of $k_{2}$, the plot in Fig. 3.7 shows that the temperature dependency is fairly well described by an Arrhenius law. However, the scaling factor 
differs a little between the 1.0 and the 0.5 bar $\mathrm{H}_{2}$ experiments, while there is only little difference in slope. For the further analysis the geometrical mean of the two expressions is used as shown in equation 3.4 .

$$
k_{2}=80.4 \cdot 10^{-6} \cdot e^{\frac{+117 \cdot 9 \cdot 10^{3}}{R T}}
$$

As for $\mathrm{k}_{3}, \mathrm{k}_{2}$ decreases with increasing temperature, meaning that the inhibiting effect of the product gas, $\mathrm{H}_{2}$, decreases with increasing temperature.

Values for $\mathrm{k}_{2}$, calculated from equation 3.4, are listed in Table 3.2.

Table 3.2. Calculated values of $k_{2}$ (best-fit parameters).

\begin{tabular}{ccccc}
\hline Temp. $\left({ }^{\circ} \mathrm{C}\right)$ & $1 / \mathrm{T}(1 / \mathrm{K})$ & $\mathrm{k}_{1}(1 / \mathrm{s}$ bar $)$ & $\mathrm{k}_{3}(1 / \mathrm{bar})$ & $\mathrm{k}_{2}(1 / \mathrm{bar})$ \\
\hline 750 & 0.0009775 & 0.001263 & 3.0999 & 79.0 \\
800 & 0.0009320 & 0.002854 & 1.7133 & 41.5 \\
850 & 0.0008905 & 0.006005 & 0.9976 & 23.1 \\
875 & 0.0008708 & 0.008548 & 0.7717 & 17.6 \\
900 & 0.0008525 & 0.011867 & 0.6080 & 13.5 \\
925 & 0.0008347 & 0.016326 & 0.4821 & 10.5 \\
\hline
\end{tabular}

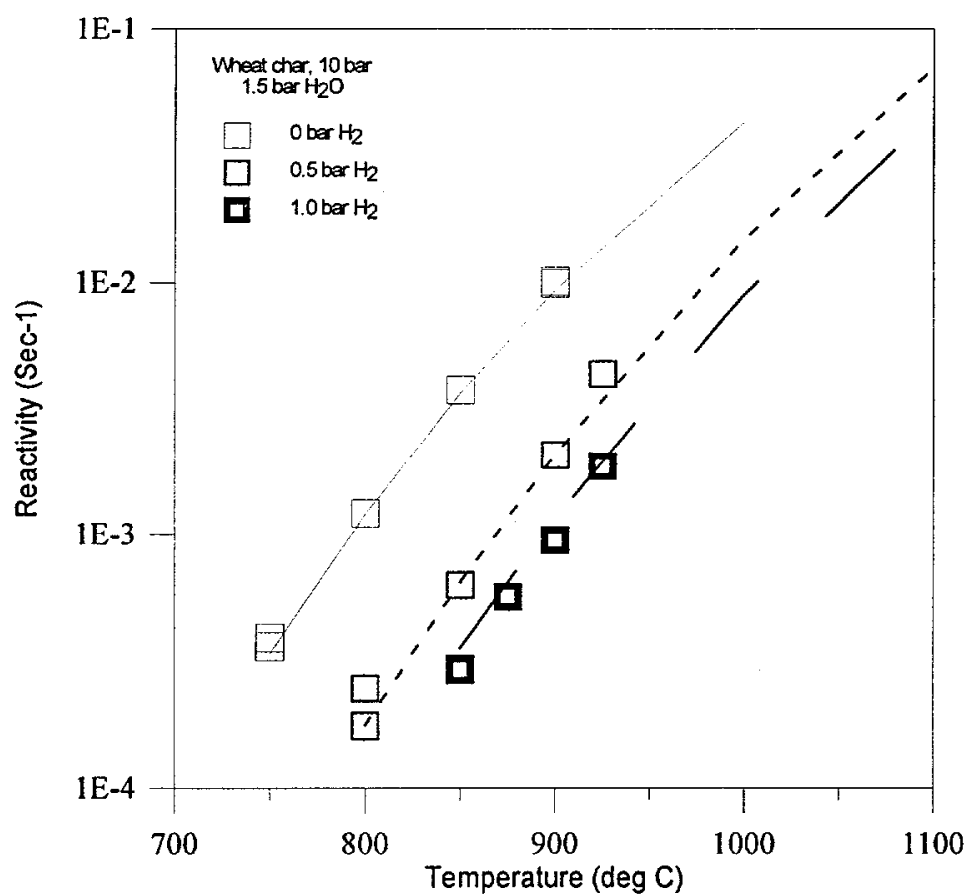

Figure 3.8. $\mathrm{H}_{2} \mathrm{O} / \mathrm{H}_{2}$ gasification of wheat char. Experimental data and the LangmuirHinshelwood law

As seen from Figures 3.8 and 3.5 the Langmuir-Hinshelwood rate law represents the experimental data accurately, with respect to the effect on the reactivity of both temperature and partial pressure of $\mathrm{H}_{2} \mathrm{O}$ and $\mathrm{H}_{2}$. Both reactivity limitation and inhibition effects decrease with increasing temperature reflected by the negative pseudo-activation energies of $\mathrm{k}_{2}$ and $\mathrm{k}_{3}$. The inhibiting effect of the product gas $\mathrm{H}_{2}$ at 1 bar partial pressure is seen to be quite significant by decreasing the reactivity by one order of magnitude at $850^{\circ} \mathrm{C}$, relevant for fluid-bed applications. For entrained-flow reactors operating with higher partial pressures of $\mathrm{H}_{2}(5 \mathrm{bar})$ the inhibiting effect will presumably be significant at temperatures as high as $1500^{\circ} \mathrm{C}$, which is also illustrated in figure 3.8 . 


\subsection{Influence of total pressure}

The influence of total gasification pressure at constant $\mathrm{H}_{2} \mathrm{O}$ partial pressure has been investigated at $1-10$ bar total pressure and $0.15-0.75$ bar $\mathrm{H}_{2} \mathrm{O}$ in the absence of $\mathrm{H}_{2}$. In Figures 3.9 to 3.11 the reactivity as a function of temperature is seen for $\mathrm{H}_{2} \mathrm{O}$ partial pressures $0.75,0.35$ and 0.15 bar. For experimental reasons not all combinations of total pressure and $\mathrm{H}_{2} \mathrm{O}$ were possible

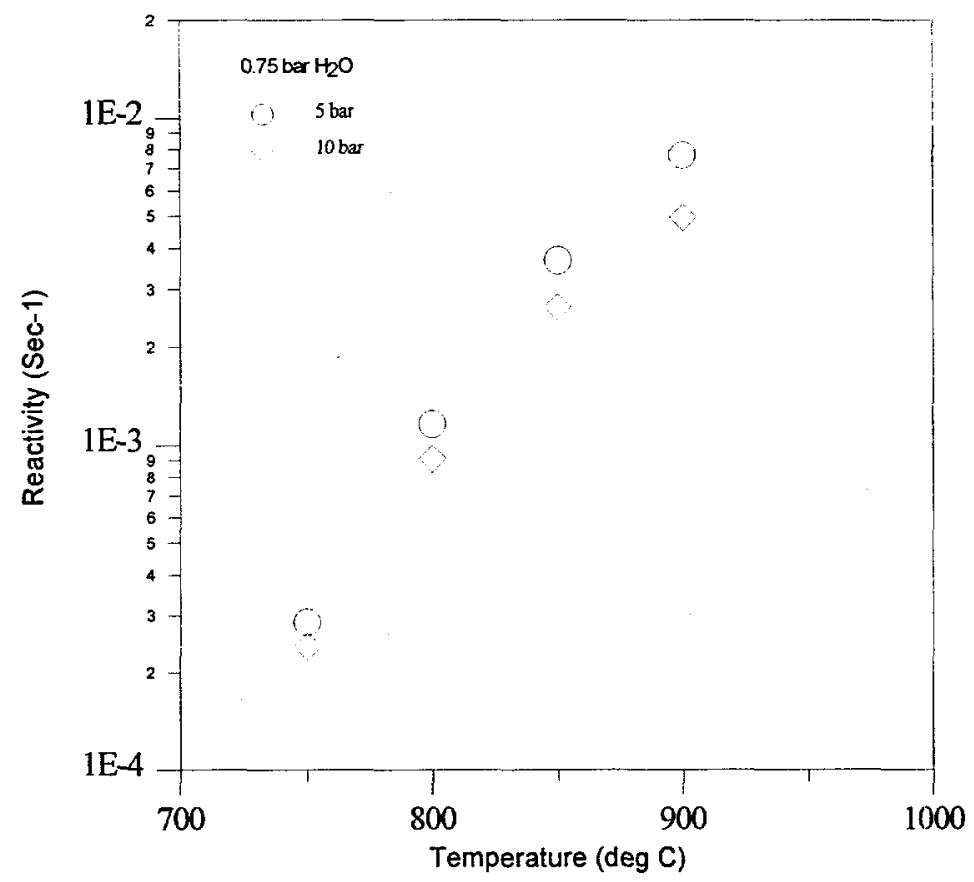

Figure 3.9. Gasification of wheat char at 0.75 bar $\mathrm{H}_{2} \mathrm{O}$ partial pressure.

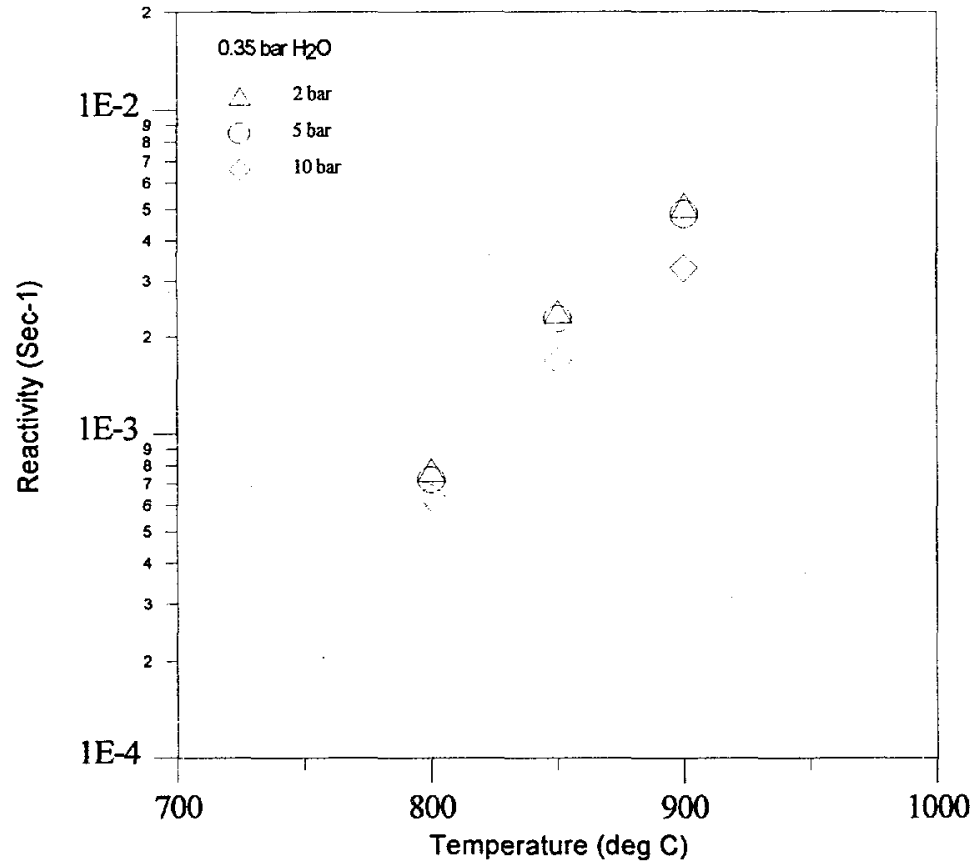

Figure 3.10. Gasification of wheat char at 0.35 bar $\mathrm{H}_{2} \mathrm{O}$ partial pressure. 


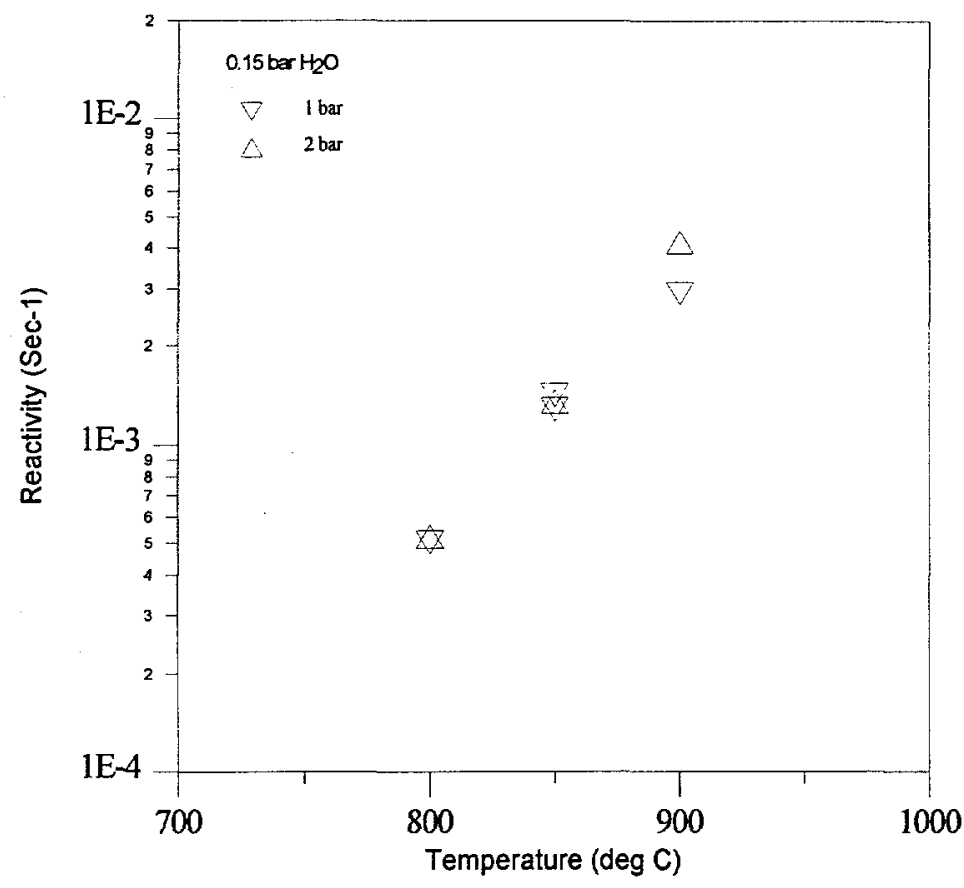

Figure 3.11. Gasification reactivity of wheat char at 0.15 bar $\mathrm{H}_{2} \mathrm{O}$ partial pressure.

At 0.75 and 0.35 bar $\mathrm{H}_{2} \mathrm{O}$ (figures 3.9 and 3.10) there seems to be a negative influence on the reactivity of increased total pressure from 5 to 10 bar: a decrease of $20 \%$ at 750 $800^{\circ} \mathrm{C}$ and more than $50 \%$ at $900^{\circ} \mathrm{C}$. At a $\mathrm{H}_{2} \mathrm{O}$ partial pressure of 0.15 bar there is no significant difference between 1 and 2 bar. At these low $\mathrm{H}_{2} \mathrm{O}$ pressure tests the steam generator was operating at the very low side of its capacity range, and instabilities of the steam production rate may have occurred.

A similar effect was also observed for $\mathrm{CO}_{2}$ gasification (Illerup and Rathmann, 1996). However, these experimental series are not sufficiently accurate to conclude whether the influence of total pressure is a real physical-chemical effect. Thus, a temperature post-calibration of the PTGA performed by Sørensen (1997) showed that the (small) temperature difference between the measuring thermocouple and the sample is affected by the total pressure, and that this, in turn, could explain part of the apparent pressure effect on the reactivity. From the 0.15 bar $\mathrm{H}_{2} \mathrm{O}$ gasification measurements no clear conclusion can be drawn regarding the total pressure behaviour due to the uncertainty of a stable steam supply.

\subsection{Screening of different biomasses}

The influence of fuel type on the gasification rate has been tested with four different types of biomasses: wheat straw, barley straw, willow and elephant grass. The experimental conditions are given in Table 3.3.

Table 3.3. Gasification of wheat, barley, willow and giganteus with $\mathrm{H}_{2} \mathrm{O}$.

\begin{tabular}{lrl} 
Particle size & $<150$ & $\mu \mathrm{m}$ \\
Pyrolysis temperature & 900 & ${ }^{\circ} \mathrm{C}$ \\
Pyrolysis pressure & 15 & $\mathrm{bar}$ \\
Pyrolysis time & $2-3$ & $\mathrm{~s}$ \\
Gasification temperature & $650-850$ & ${ }^{\circ} \mathrm{C}$ \\
Gasification pressure & 10 & $\mathrm{bar}$ \\
Partial pressure of $\mathrm{H}_{2} \mathrm{O}$ & 1.5 & $\mathrm{bar}$ \\
Partial pressure of $\mathrm{H}_{2}$ & 0 & $\mathrm{bar}$ \\
\hline
\end{tabular}


The screening tests are listed completely in Appendix B.

The different kinds of biomasses have been compared with respect to the $\mathrm{H}_{2} \mathrm{O}$ reactivity in the absence of $\mathrm{H}_{2}$. Figure 3.12 shows the reactivity as a function of temperature for the experiments carried out with 1.5 bar $\mathrm{H}_{2} \mathrm{O}$. The reactivity for the barley straw is nearly 10 times higher than that for wheat straw and giganteus, and 5 times higher than that found for willow. The ranking of the different biomass types are the same as for $\mathrm{CO}_{2}$ gasification as reported by Illerup and Rathmann, (1996).

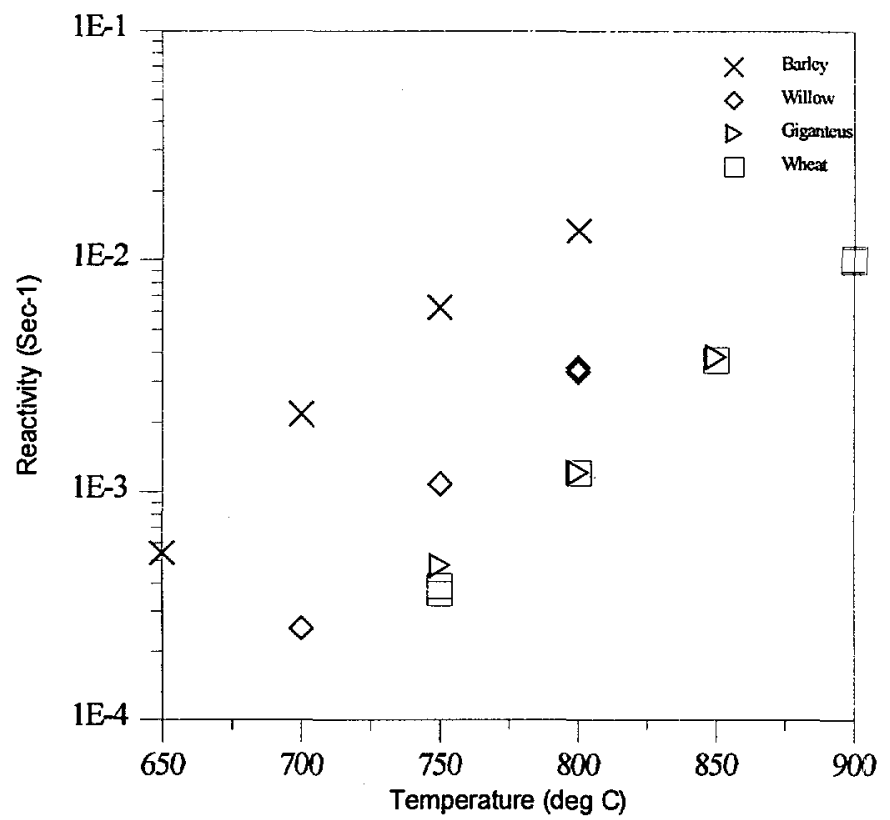

Figure 3.12. Comparison of gasification reactivities of four different biomass fuels.

As seen from Appendix D the variation in the ash composition is large for the four biomasses. Especially in the content of potassium the barley straw has a much higher value than the other biomasses. It is well established that potassium catalyzes the reaction between $\mathrm{H}_{2} \mathrm{O}$ and char, which may explain the much higher reactivity rate of barley.

\section{Conclusion}

A thorough experimental study of the $\mathrm{H}_{2} \mathrm{O}$ gasification char-reactivity of wheat straw, barley straw, willow, giganteus at 1-10 bar total pressure, $0.15-1.5$ bar $\mathrm{H}_{2} \mathrm{O}$ and $0-1.0$ bar $\mathrm{H}_{2}$ and $750-925^{\circ} \mathrm{C}$, was performed in a Pressurized Thermogravimetric Analyzer.

Kinetic experiments with char of wheat straw at 10 bar total pressure showed that the reactivity increases with increasing temperature and increasing partial pressure of $\mathrm{H}_{2} \mathrm{O}$. However, the effect of reactivity limitation at high $\mathrm{H}_{2} \mathrm{O}$ concentration is visible in the whole $\mathrm{H}_{2} \mathrm{O}$ range as the reactivity varies less than in proportion to the partial pressure of $\mathrm{H}_{2} \mathrm{O}$. In the experiments with different contents of $\mathrm{H}_{2}$ in the reaction gas a large inhibiting effect on the reactivity by $\mathrm{H}_{2}$ was observed. Both the reactivity limitation and inhibition effects were observed to decrease clearly with increasing temperature.

The experimental data for wheat straw char kinetics at 10 bar are very well described by the Langmuir-Hinselwood equation including both inhibition with $\mathrm{H}_{2}$ and reactivity limitation at high $\mathrm{H}_{2} \mathrm{O}$ concentration. The value of the main activation energy $\mathrm{E}_{1}=149$ $\mathrm{kJ} /$ mole, describing the temperature dependence at low $\mathrm{H}_{2} \mathrm{O}$ concentration, is close to the experimental values reported by other workers for biomass and coal, and is about the same as found in a previous study of $\mathrm{CO}_{2}$ gasification. 
Experiments at varying total pressure and constant $\mathrm{H}_{2} \mathrm{O}$ partial pressure in the absence of $\mathrm{H}_{2}$ indicated a negative influence on the reactivity by the total pressure, not accounted for by the Langmuir-Hinshelwood rate law. Post-calibration of the experimental equipment by Sørenesen (1997) showed that for some part this observation can be explained by a pressure dependent temperature defect in the control of the sample temperature. More detailed studies will be necessary to give evidence for such a total pressure effect.

A screening study for all four biomass types at 10 bar total pressure, 1.5 bar $\mathrm{H}_{2} \mathrm{O}$, no $\mathrm{H}_{2}$ and $650-900^{\circ} \mathrm{C}$ showed that while the temperature dependences were rather equal the absolute reaction rate had a spread of 10 times from wheat and giganteus as the lowest to barley as the highest. Chemical analyses of the biomasses show that the variation in the content of $\mathrm{H}, \mathrm{C}$ and $\mathrm{N}$ is small while the ash composition as well as the fusion temperatures are very different. Especially the content of potassium has a much higher value in barley straw than in the other biomasses. This may explain why barley straw has the highest reactivity.

For both fluid-bed and entrained-flow gasifier types the present experimental study indicates that the inhibiting effect of the product gas $\mathrm{H}_{2}$ is of significant importance, decreasing the reactivity by roughly one order of magnitude at relevant product gas partial pressures.

\section{Acknowledgement}

Thanks are due to Torben D. Pedersen and Peter Mørk, who performed a major part of the construction and modification of the PTGA necessary to enable the steam gasification experiments to take place. Their skill and enthusiasm were important conditions for completing this experimental study and are gratefully acknowledged. Also, thanks are due to L.H.Sørensen, ReaTech, for his review of and comments to the present report. Financial support by the power utility associations Elsam and Elkraft and the Danish Ministry of Energy is also acknowledged. 


\section{References}

Gjernes, E., Fjellerup, J., Hansen, L. K., Rathmann, O., Kirkegaard, M., Bak, J., Stoholm, P., Illerup, J. B., Hald, P. and Olsen, A., 1995, Theoretical and Experimental Investigations of coal and biomass combustion and gasification properties at high pressure and temperature - Final Report. Risø-R-859(EN), Risø National Laboratory, Denmark.

Hansen, L. K., Fjellerup, J., Stoholm, P. and Kirkegaard. M., 1995, The pressurized Entrained Flow Reactor at Risø. Design Report Risø-R-822(EN), Risø National Laboratory, Denmark.

Illerup, J. B. and Rathmann, O, 1996, $\mathrm{CO}_{2}$ Gasification of Wheat Straw, Barley Straw, Willow and Giganteus. Risø-R-873(EN), Risø National Laboratory, Denmark.

Laurendeau, N.M. (1978). Heterogeneous Kinetics of Coal Char Gasification and Combustion. Prog.Energy Combust. Sci. 4, pp 221-270.

Mühlen, H.-J., van Heek, K.H. and Jüntgen, H. (1985). Kinetic studies of char in the presence of $\mathrm{H}_{2}, \mathrm{CO}_{2}$ and $\mathrm{CO}$. Fuel 64, pp 944-949.

Moilanen,A., Saviharju,K. and Harju,T. (1993). Steam gasification reactivities of various fuel chars, in: Advances in Thermochemical Biomass Conversion, pp.131-141, edited by Bridgwater, A.V., Blackie Academic \& Professional (1993).

Overend, R. P., Milne, T. A. and Mudge, L. K. (1985). Fundamentals of Thermochemical Biomass Conversion, Elsevier Applied Science Publishers LTD, 619689.

Rathmann, O., Stoholm, P. and Kirkegaard, M. (1995). The Pressurized Thermogravimetric Analyzer at the Department of Combustion Research, Risø: Technical Description of the Instrument. Risø-R-823(EN), Risø National Laboratory, Denmark.

Reif, A. E. (1952). The mechanism of the carbon dioxide-carbon reaction, J. Phys. Chem., 56, 785 .

Sørensen, L.H., ReaTech, CAT Science Center, Frederiksborgvej 399, P.O.Box 30, DK4000 Roskilde, Denmark. Private communication (1997). 
7. Appendices 


\section{Appendix A}

\section{Modification of the Risø PTGA: Establishment of Forced Purge Flow into the Balance Unit.}

Ole Rathmann

\section{INTRODUCTION}

Originally, the Risø PTGA used a flow configuration as described by Rathmann et al. (1995), where the purge flow through the balance unit was obtained indirectly by suction from the pressure vessel volume by the difference between the specified exit flow and the somewhat smaller specified test gas inlet flow. The advantage of this configuration is the vanishing pressure difference between the pressure vessel volume on the one hand and the balance unit housing, reaction chamber and connected gas flow lines on the other. Thereby complete tightness between the last-mentioned components in the pressure vessel is not so critical. However, the purge flow gets extremely sensitive to fluctuations in the inlet test gas flow, e.g. due to instabilities in steam generator operation during steam gasification experiments.

During steam gasification tests with this original flow configuration condensation in the balance unit was impossible to avoid, and the weight signals were spoiled due to droplets clinging to the balance arm. The reason is believed to be short-period flow reversals in the purge flow, due to fluctuations in the generated steam flow from the steam generator, as explained above.

As a consequence, the flow configuration has been changed, so that the purge flow is forced through the balance unit by a direct connection between a mass flow controller and the balance unit housing. This should to a much higher degree ensure a positive purge flow to prevent the reaction test gas containing $\mathrm{H}_{2} \mathrm{O}$ from entering the balance unit housing to cause condensation. 


\section{DESCRIPTION OF CONFIGURATION B.}

The new configuration is shown in Fig. 1.1 and Fig. 1.2.

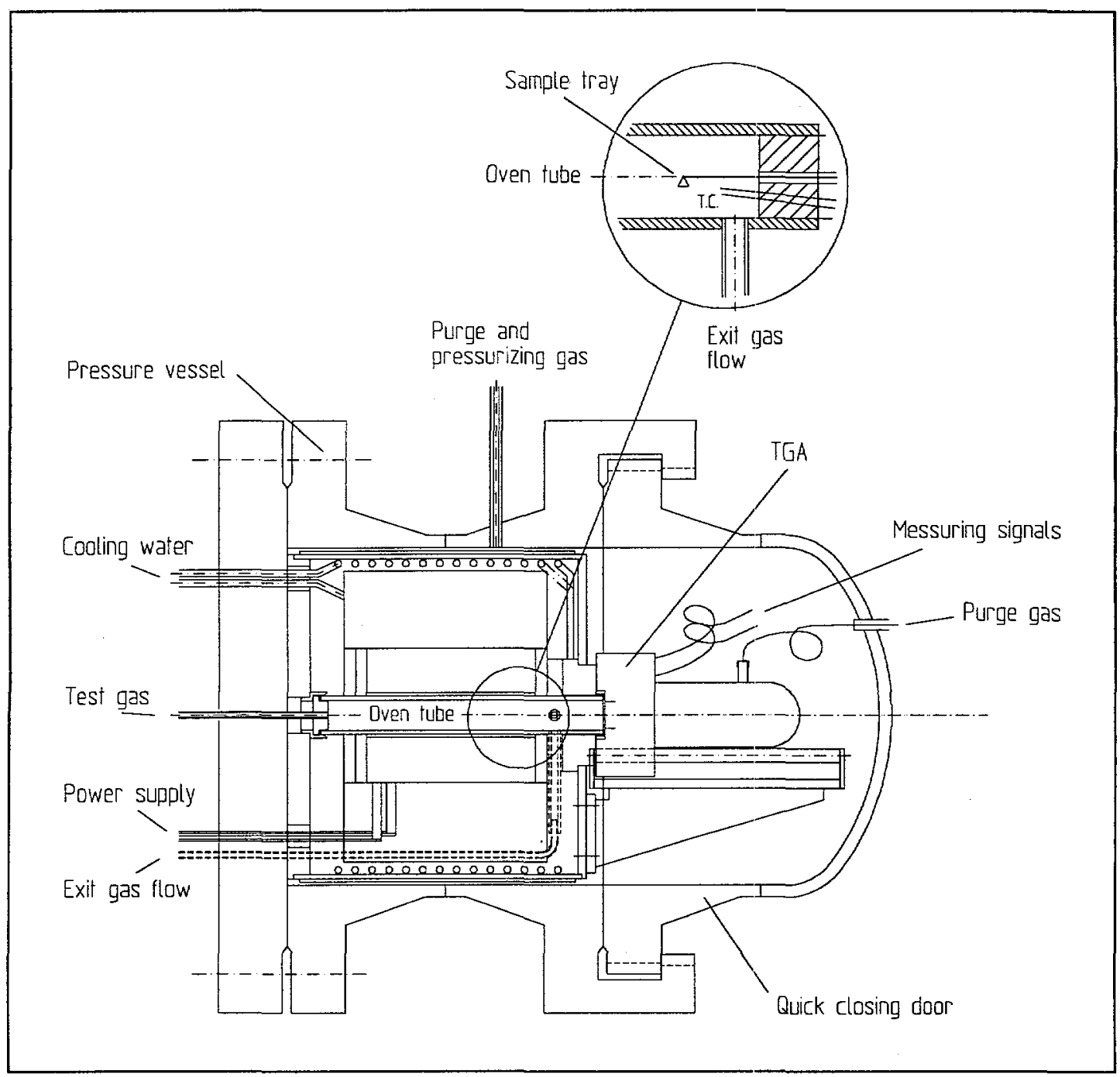

Fig. 1.1. Pressure vessel with furnace and balance unit.

The physical connection for the purge gas flow from the mass flow controller to the balance housing is established through a feed-through placed in the quick-closing door of the pressure vessel as shown in Fig. 1.1. 


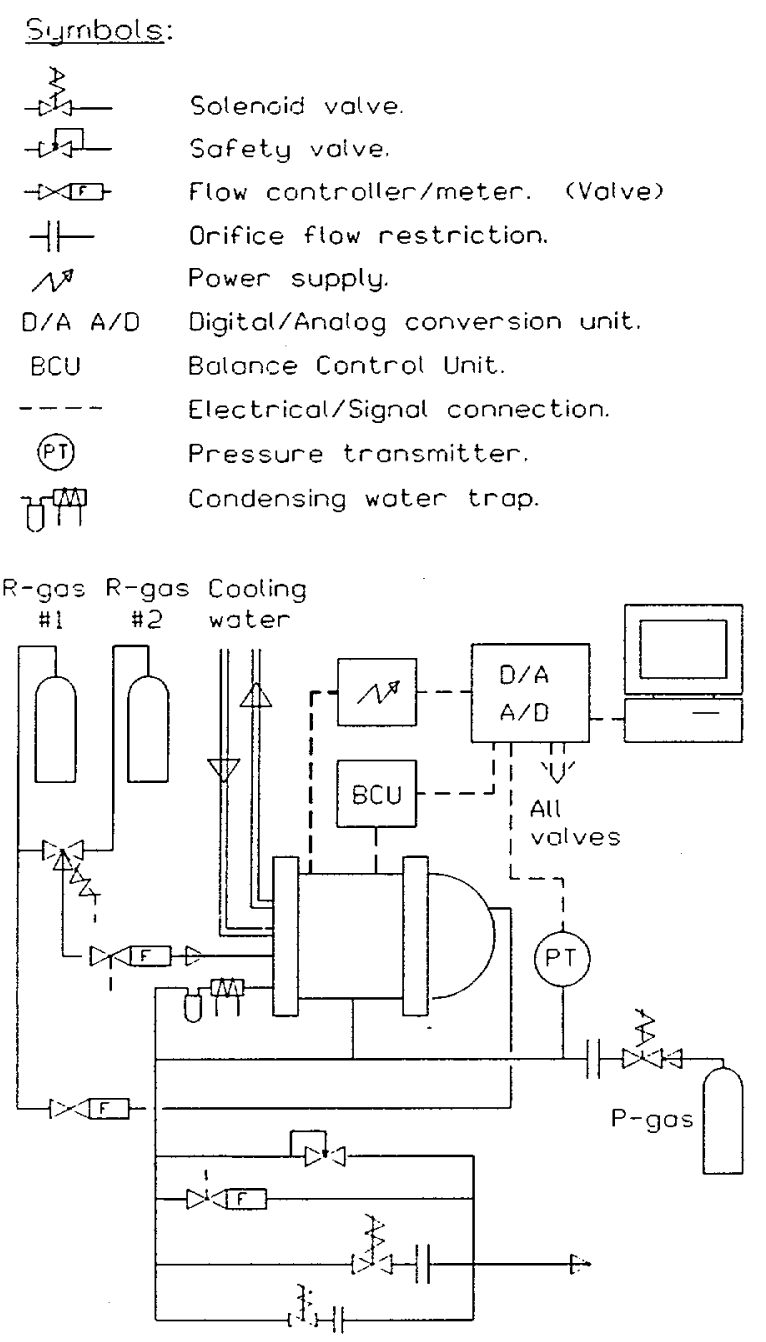

Fig. 1.2. PTGA System layout.

$R$-gas \#I and \#2: Selectable 'reaction' test gases. R-gas \#I is normally inert ( $\left.N_{2}\right)$ and is also used as purge gas.

P-gas: Pressurizing gas.

In the case of steam gasification experiments, steam is added from a steam generator into the reaction gas flow line between the mass flow controller and the centre of the back wall (left) of the pressure vessel.

The two solenoid pressure relief valves in connection with flow limiting orifices, seen in the bottom of the figure, differ from each other in that the upper one, with the larger orifice (FDV), is of the normally-closed type, and is used for normal pressure blow-down, while the lower one with the smaller orifice (SDV) is of the normallyopen type and is used to relieve the pressure in case of such abnormal situations as overpressure, overtemperature or electrical power fall-out.

Fig. 1.2 shows the modified flow path configuration. This configuration is similar to that used by Dobner et al. (1976). Following a condensing water trap outside the vessel the exit flow is led to a pressure balance line connected to the pressure vessel volume. Pressurization and depressurization (through solenoid valves in connection 
with flow- limiting orifices) and pressure control during constant pressure conditions (by a mass flow controller) take place via this pressure balance line.

Due to the pressure drop through the narrow exit gas flow lines at some places the 'internal components' - the balance unit housing and the reaction chamber tube and connected flow lines - will be at a certain overpressure relative to the pressure vessel volume. Preliminary tests indicates overpressures of about 10-30 mbar at operation at 20 bar. This means that the tightness of the fittings between these internal components' is important to avoid humid gas to leak out into the pressure vessel volume, where it may condense and thereby damage the insulation material of the furnace. Special attention has been given to the fittings between the reaction tube and the balance housing and the steel capillary tube exit flow line. The fitting between reaction tube and the balance housing is sealed with a rubber gasket, while the fitting between the exit flow branch of the reaction tube (quartz) and the steel capillary tube is made with a ceramic tube with teflon tape as the sealing material as shown in Fig. 1.3. The tightness of these fittings have been tested at atmospheric pressure at realistic overpressures, temperatures and flow rates, and it was found that the leakage's were less than $1 \%$ of the exit flow rate.

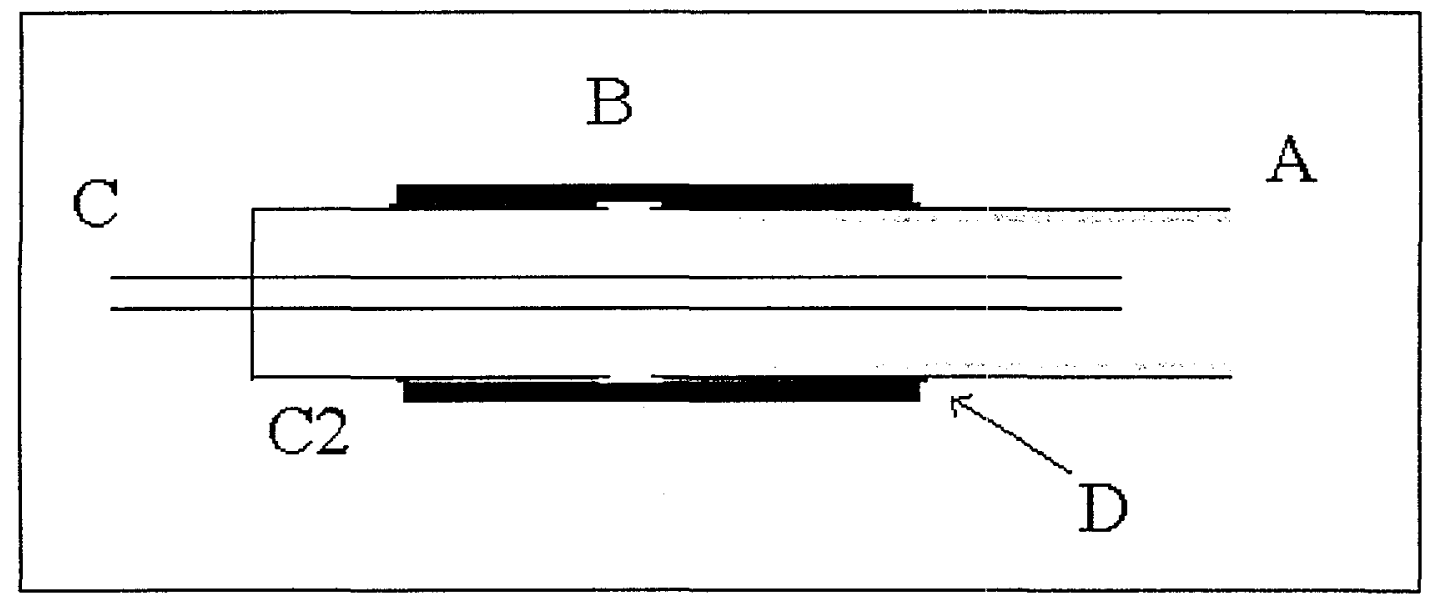

Fig. 1.3. Fitting between reaction tube exit branch and capillary tube.

A: Reaction tube exit flow branch (quartz); $B$ : ceramic fitting tube; $C$ : Capillary tube (steel); C2: transition piece on capillary, also serving as thermal relief; $D$ : teflon tape sealing.

\section{PRESSURE CONTROL}

In the new configuration the pressure control strategy has been changed so that the pressure is kept constant by adjusting the exit gas flow (instead of adjusting a 'pressure-sustaining flow' into the pressure vessel). The new control arrangement is illustrated in Fig. 2.1. 


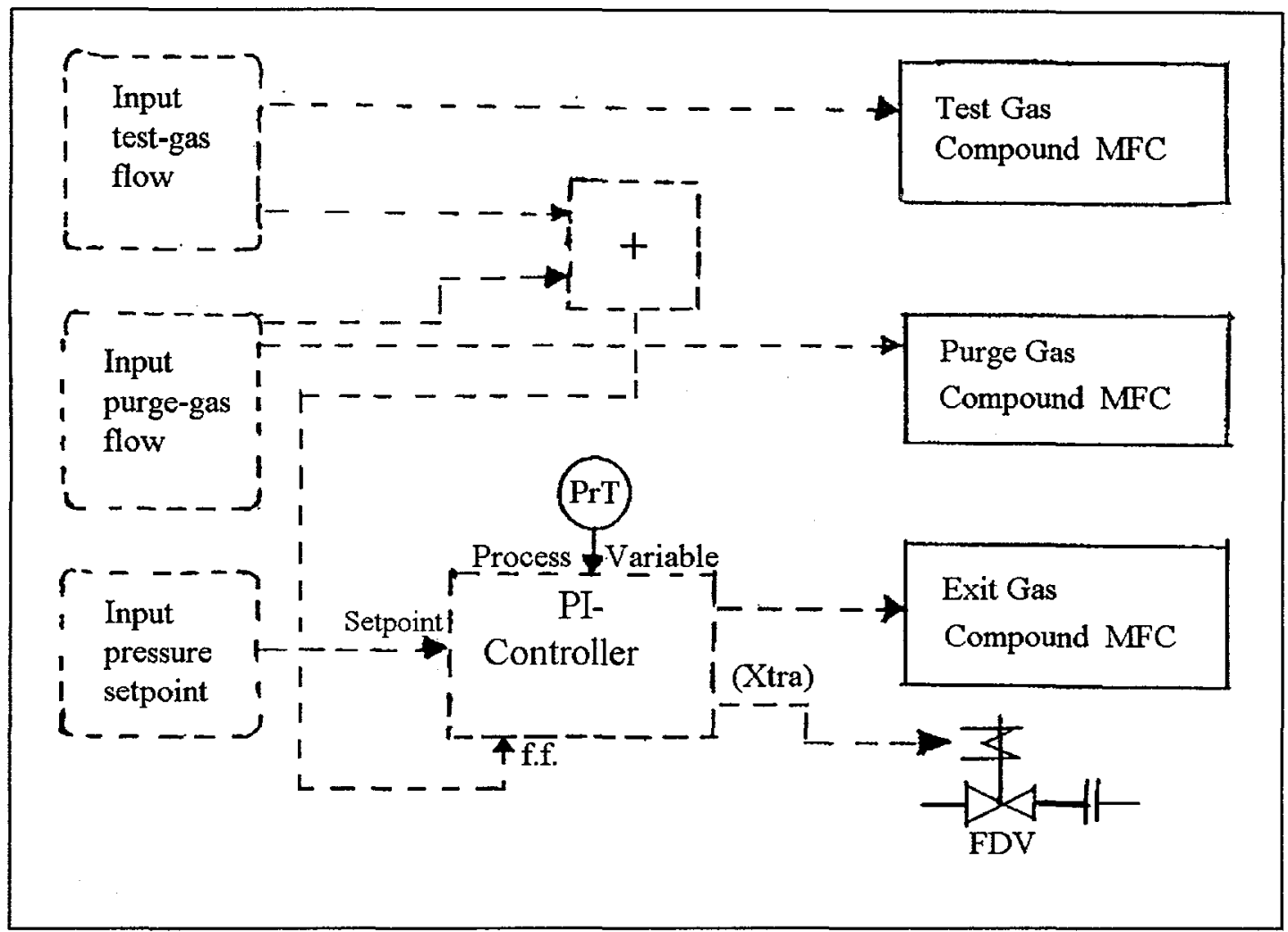

Fig. 2.1. Pressure control arrangement.

For the case that the capacity of the exit gas compound mass-flow controller is not sufficient for the pressure control, this mass-flow controller is supplemented with short-period openings of the fast depressurization solenoid valve FVD to provide extra exit gas flow.

$\operatorname{Pr} T=$ Pressure transmitter, $f$. . $=$ Feed forward .

\section{REFERENCES.}

Dobner, S. et al. (1976). A thermobalance for high pressure process studies. Thermochimica Acta 16, pp251-265.

Rathmann, O., Stoholm, P. and Kirkegaard, M.. (1995). The Pressurized Thermogravimetric Analyzer at the Department of Combustion Research, Risø: Technical Description of the Instrument. Risø-R-823(EN), Risø National Laboratory, Denmark. 


\section{APPENDIX B}

\section{PTGA experimental plan for steam gasification}

\begin{tabular}{|c|c|c|c|c|c|c|c|c|c|c|c|}
\hline & $P_{\text {tot }}$ & $\mathrm{PH}_{2} \mathrm{O}$ & $\mathrm{PH}_{2}$ & 650 & 700 & 750 & 800 & 850 & 875 & 900 & 925 \\
\hline \multirow[t]{10}{*}{ Wheat } & 10 & 1,5 & & & & $\begin{array}{l}\mathrm{HH} 2 \mathrm{O} \# 07 \\
\mathrm{HH} 2 \mathrm{O} \# 15\end{array}$ & $\begin{array}{l}\mathrm{HH} 2 \mathrm{O} \# 05 \\
\mathrm{HH} 2 \mathrm{O} \# 09\end{array}$ & $\mathrm{HH} 2 \mathrm{O} \# 10$ & & $\begin{array}{l}\mathrm{HH} 2 \mathrm{O} \# 32 \\
\mathrm{HH} 2 \mathrm{O} \# 11\end{array}$ & \\
\hline & 10 & 0,75 & & & & $\mathrm{HH} 2 \mathrm{O} \# 17$ & $\mathrm{HH} 2 \mathrm{O} \# 13$ & $\mathrm{HH} 2 \mathrm{O} \# 12$ & & $\begin{array}{l}\mathrm{HH} 2 \mathrm{O} \# 18 \\
\mathrm{HH} 2 \mathrm{O} \# 19\end{array}$ & \\
\hline & 10 & 0,35 & & & & $\mathrm{HH} 2 \mathrm{O} \# 23$ & $\mathrm{HH} 2 \mathrm{O} \# 22$ & $\mathrm{HH} 2 \mathrm{O} \# 21$ & & $\mathrm{HH} 2 \mathrm{O} \# 20$ & \\
\hline & 10 & 1,5 & 0,5 & & & & $\begin{array}{l}\mathrm{HH} 2 \mathrm{O} \# 27 \\
\mathrm{HH} 2 \mathrm{O} \# 28\end{array}$ & $\mathrm{HH} 2 \mathrm{O} \# 16$ & & $\mathrm{HH} 2 \mathrm{O} \# 29$ & $\mathrm{HH} 2 \mathrm{O} \# 30$ \\
\hline & 10 & 1,5 & 1 & & & & & $\mathrm{HH} 2 \mathrm{O} \# 31$ & $\mathrm{HH} 2 \mathrm{O} \# 35$ & $\mathrm{HH} 2 \mathrm{O} \# 33$ & $\mathrm{HH} 2 \mathrm{O} \$ 34$ \\
\hline & 5 & 0,75 & & & & $\begin{array}{l}\mathrm{HH} 2 \mathrm{O} \# 26 \\
\mathrm{HH} 2 \mathrm{O} 338\end{array}$ & $\begin{array}{l}\mathrm{HH} 2 \mathrm{O} 24 \\
\mathrm{HH} 2 \mathrm{O} \# 37\end{array}$ & $\begin{array}{l}\mathrm{HH} 2 \mathrm{O} \# 14 \\
\mathrm{HH} 2 \mathrm{O} \# 36\end{array}$ & & $\begin{array}{l}\mathrm{HH} 2 \mathrm{O} \# 25 \\
\mathrm{HH} 2 \mathrm{O} \# 39\end{array}$ & \\
\hline & 5 & 0,35 & & & & & $\mathrm{HH} 2 \mathrm{O} \# 42$ & $\mathrm{HH} 2 \mathrm{O} \# 40$ & & $\mathrm{HH} 2 \mathrm{O} \# 41$ & \\
\hline & 2 & 0,35 & & & & & $\mathrm{HH} 2 \mathrm{O} \# 45$ & $\begin{array}{l}\mathrm{HH} 2 \mathrm{O} \# 43 \\
\mathrm{HH} 2 \mathrm{O} \# 44\end{array}$ & & HH2O\#49 & \\
\hline & 2 & 0,15 & & & & & $\mathrm{HH} 2 \mathrm{O} \# 51$ & HH2O\#50 & & HH2O\#52 & \\
\hline & 1 & 0,15 & & & & & $\mathrm{HH} 2 \mathrm{O} \# 47$ & $\begin{array}{l}\mathrm{HH} 2 \mathrm{O} \# 01 \\
\mathrm{HH} 2 \mathrm{O} 466\end{array}$ & & HН2O\#48 & \\
\hline Willow & 10 & 1,5 & & & $\mathrm{HH} 2 \mathrm{O} \# 54$ & $\mathrm{HH} 2 \mathrm{O} \# 53$ & $\begin{array}{l}\mathrm{HH} 2 \mathrm{O} \# 06 \\
\mathrm{HH} 2 \mathrm{O} \# 55\end{array}$ & & & & \\
\hline Giganteus & 10 & 1,5 & & & & $\mathrm{HH} 2 \mathrm{O} \# 57$ & $\mathrm{HH} 2 \mathrm{O} \# 56$ & $\mathrm{HH} 2 \mathrm{O} \# 58$ & & & \\
\hline Barley & 10 & 1,5 & & $\mathrm{HH} 2 \mathrm{O} \# 61$ & $\mathrm{HH} 2 \mathrm{O} \# 60$ & $\mathrm{HH} 2 \mathrm{O} \# 62$ & $\mathrm{HH} 2 \mathrm{O} \# 59$ & & & & \\
\hline & & & & & & & & & & & \\
\hline
\end{tabular}

HH2O\#X: Char\#1 HH2O\#X: Char\#2 
Appendix C

List of inverse reactivities. 


\begin{tabular}{|c|c|c|c|c|c|c|c|c|c|c|c|c|c|c|c|c|c|c|c|}
\hline $\begin{array}{l}0 \\
n \\
0 \\
0 \\
0 \\
0 \\
0\end{array}$ & 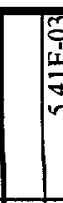 & 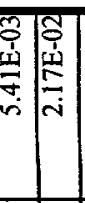 & 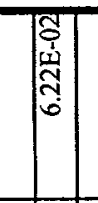 & 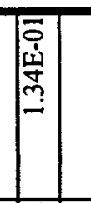 & & & & & & $\left|\begin{array}{c}0 \\
0 \\
0 \\
\vdots \\
0 \\
0 \\
\vdots \\
0 \\
0 \\
0\end{array}\right|$ & 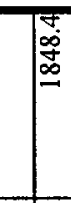 & 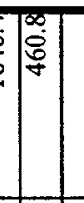 & 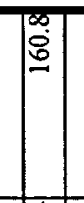 & $\stackrel{F}{*}$ & & & & & \\
\hline $\begin{array}{l}0 \\
n \\
0 \\
0 \\
0 \\
00 \\
00 \\
0\end{array}$ & & & 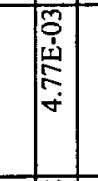 & 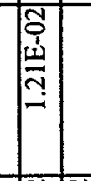 & 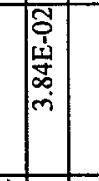 & & & & & $\left|\begin{array}{c}0 \\
0 \\
0 \\
0 \\
0 \\
0.00 \\
0.00\end{array}\right|$ & & & 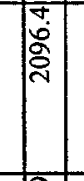 & $\mid \begin{array}{l} \pm \\
\dot{J} \\
\infty\end{array}$ & 它 & & & & \\
\hline $\begin{array}{l}0 \\
0 \\
n \\
0 \\
0 \\
0 \\
0 \\
0 \\
\end{array}$ & & 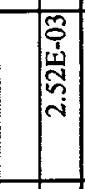 & 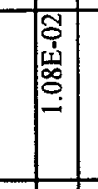 & 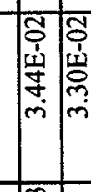 & & & & & & $\mid \begin{array}{c}0 \\
0 \\
n \\
0 \\
0 \\
3 \\
3\end{array}$ & & 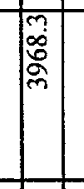 & $\mid \begin{array}{l}\text { के } \\
\hat{े}\end{array}$ & बे & & & & & \\
\hline 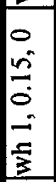 & 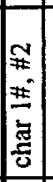 & & & 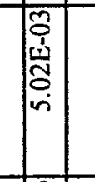 & 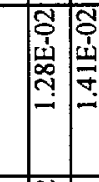 & & 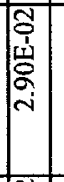 & & & $\begin{array}{c}0 \\
0 \\
0 \\
0 \\
-5 \\
\frac{1}{3}\end{array}$ & 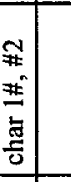 & & & $\mid \begin{array}{c}0 \\
\dot{\alpha} \\
2\end{array}$ & $\frac{m}{2}$ & \begin{tabular}{|l|} 
\\
2 \\
2 \\
2 \\
2
\end{tabular} & 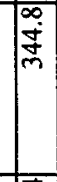 & & \\
\hline $\begin{array}{l}0 \\
0 \\
n \\
0 \\
0 \\
\tilde{N} \\
\frac{1}{3} \\
\end{array}$ & 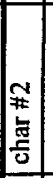 & & & 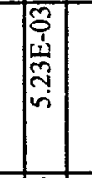 & 总 & & 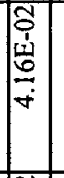 & & & $\begin{array}{c}0 \\
0 \\
n \\
0 \\
0 \\
n \\
\frac{1}{3} \\
\frac{1}{3}\end{array}$ & 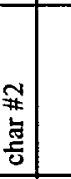 & & & 尊 & $\mid \begin{array}{l}\frac{1}{2} \\
\frac{1}{2}\end{array}$ & & 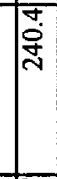 & & \\
\hline \begin{tabular}{|l|}
0 \\
0 \\
$n$ \\
0 \\
0 \\
$i$ \\
$\tilde{n}$ \\
$\frac{1}{3}$ \\
\end{tabular} & 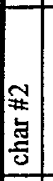 & & & 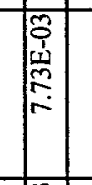 & 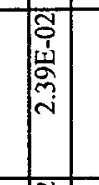 & & 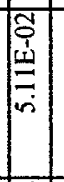 & & & $\begin{array}{c}0 \\
0 \\
0 \\
0 \\
0 \\
0 \\
3 \\
3\end{array}$ & 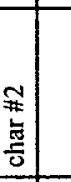 & & & 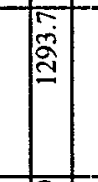 & $\begin{array}{l}F \\
\infty \\
F\end{array}$ & & $\hat{\tilde{\Omega}}$ & & \\
\hline $\begin{array}{l}0 \\
0 \\
\infty \\
n \\
0 \\
0 \\
n \\
0 \\
3 \\
3 \\
\end{array}$ & 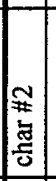 & & & 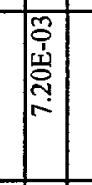 & 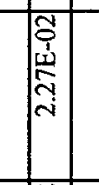 & & 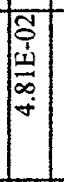 & & & $\begin{array}{c}0 \\
0 \\
0 \\
0 \\
0 \\
0 \\
0 \\
\frac{1}{3} \\
0\end{array}$ & 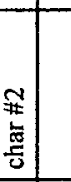 & & & $\begin{array}{l}2 \\
\infty \\
\infty \\
\infty \\
\infty\end{array}$ & $\begin{array}{l}n \\
\vdots \\
\vdots \\
q\end{array}$ & & 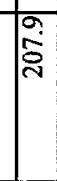 & & \\
\hline $\begin{array}{l}0 \\
0 \\
n \\
n \\
0 \\
0 \\
n \\
\frac{n}{3} \\
\end{array}$ & \begin{tabular}{|l|} 
\\
\\
$\frac{7}{0}$ \\
0
\end{tabular} & & 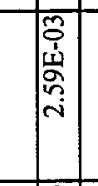 & 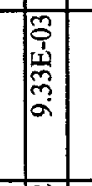 & 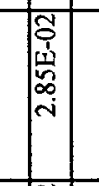 & & $\mid \begin{array}{l}0 \\
0 \\
0 \\
0 \\
0 \\
0 \\
0\end{array}$ & & & 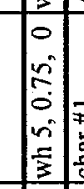 & 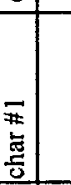 & & 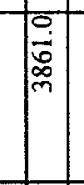 & $\begin{array}{l} \\
\\
\\
\\
\end{array}$ & 层 & & 焉 & & \\
\hline $\begin{array}{l}0 \\
0 \\
n \\
0 \\
0 \\
n \\
n \\
0 \\
3 \\
\end{array}$ & 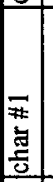 & & $\begin{array}{l}0 \\
0 \\
0 \\
0 \\
0 \\
0 \\
\sim \\
\sim\end{array}$ & 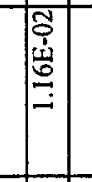 & $\mid \begin{array}{l}0 \\
0 \\
0 \\
0 \\
0 \\
m \\
m\end{array}$ & & 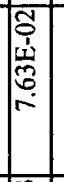 & & & $\begin{array}{c}0 \\
0 \\
n \\
0 \\
0 \\
n \\
\frac{1}{3} \\
3\end{array}$ & 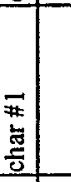 & & 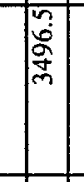 & 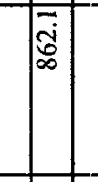 & 离 & & $\overline{\bar{m}}$ & & \\
\hline \begin{tabular}{|l|} 
\\
$n$ \\
$\vdots$ \\
0 \\
0 \\
$\tilde{a}$ \\
\end{tabular} & 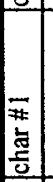 & & & & 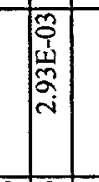 & 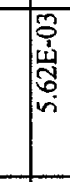 & 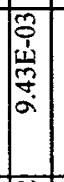 & 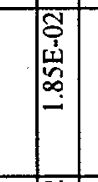 & & 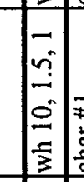 & 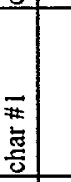 & & & & 商 & F & 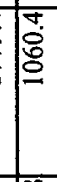 & wa & \\
\hline 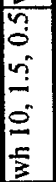 & 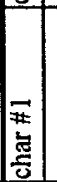 & & & 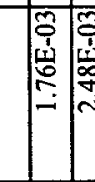 & 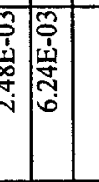 & & 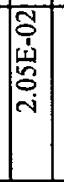 & 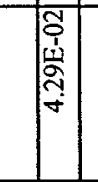 & & 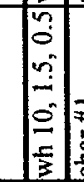 & \begin{tabular}{|}
$\frac{1}{F}$ \\
$\frac{7}{5}$ \\
\end{tabular} & & & 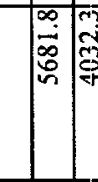 & $\mid \begin{array}{c}0 \\
\end{array}$ & & 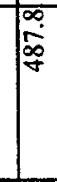 & $\bar{n}$ & \\
\hline \begin{tabular}{|l|}
0 \\
0 \\
0 \\
0 \\
0 \\
0 \\
0 \\
0 \\
0 \\
0 \\
0 \\
0
\end{tabular} & 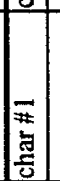 & & 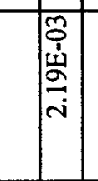 & 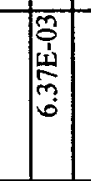 & $\mid \begin{array}{l}\overline{0} \\
0 \\
0 \\
0 \\
0 \\
0 \\
-\end{array}$ & & 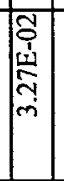 & & & {$\left[\begin{array}{c}0 \\
0 \\
0 \\
0 \\
0 \\
0 \\
0 \\
0 \\
3 \\
3\end{array}\right.$} & \begin{tabular}{|} 
F\# \\
$\frac{7}{0}$ \\
\end{tabular} & & 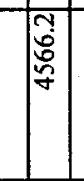 & a & 焉 & & $\begin{array}{l}\infty \\
\dot{0} \\
\dot{p}\end{array}$ & & \\
\hline 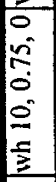 & \begin{tabular}{|l} 
F \\
F \\
尊
\end{tabular} & & 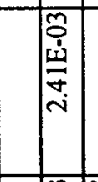 & 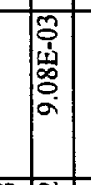 & 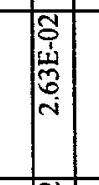 & & 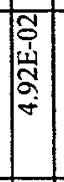 & & & $\mid \begin{array}{c}0 \\
0 \\
n \\
0 \\
0 \\
0 \\
0 \\
\overline{3} \\
\vdots\end{array}$ & 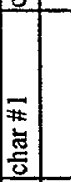 & & $\frac{\pi}{2}$ & 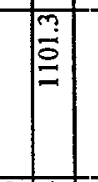 & त् & & कृ & & \\
\hline 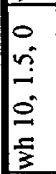 & 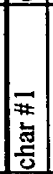 & & 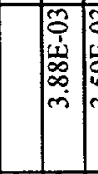 & 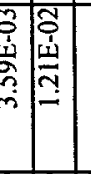 & 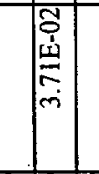 & & \begin{tabular}{|l|}
$\overline{0}$ \\
$\dot{\omega}$ \\
0 \\
\\
-
\end{tabular} & 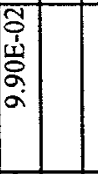 & & $\left|\begin{array}{c}0 \\
n \\
\vdots \\
0 \\
0 \\
\frac{5}{3}\end{array}\right|$ & 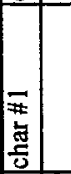 & & 色 & 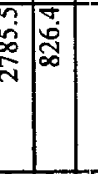 & W & & a & 官 & \\
\hline 言 & $\mid \begin{array}{l}0 \\
0 \\
0 \\
0 \\
0\end{array}$ & 융융 & 8 & 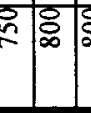 & : & \begin{tabular}{l|l}
$\infty$ \\
$\infty$
\end{tabular} & $\overline{2}$ & ৪ুন্তু & Zू. & 訔 & 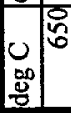 & 6 & 5 & : & $\mathbb{B}_{\infty}$ & $\infty$ & \% & $\bar{\delta}$ & \\
\hline
\end{tabular}




\section{Appendix D}

\section{Fuel analysis}

Analyses of the pulverized biomass, wheat straw, barley straw, willow and giganteus (elephant grass) have been performed by dk-TEKNIK, and the results are listed in Table D.1-D.4.

Table D.1. Proximate and ultimate analysis of the pulverized biomass.

\begin{tabular}{l|cccc|cccc}
\hline & \multicolumn{5}{|c|}{ w\% } & \multicolumn{5}{c}{ w\% (water free basis) } \\
\hline \multirow{2}{*}{ Water } & Wheat & Barley & Willow & Giganteus & Wheat & Barley & Willow & Giganteus \\
Ash & 10.0 & 12.1 & 11.1 & 14.2 & & & & \\
Sulphur & 5.8 & 2.4 & 1.9 & 1.3 & 6.4 & 2.7 & 2.1 & 1.5 \\
Volatile & 0.15 & 0.13 & 0.08 & 0.09 & 0.17 & 0.15 & 0.10 & 0.10 \\
Hydrogen & 69.6 & 70.2 & 69.9 & 70.4 & 77.3 & 79.9 & 78.6 & 82.1 \\
Carbon & 5.2 & 5.4 & 5.9 & 5.4 & 5.8 & 6.14 & 6.6 & 6.3 \\
Nitrogen & 42.5 & 41.5 & 43.8 & 41.5 & 47.2 & 47.2 & 49.3 & 48.4 \\
Chlorine & 0.6 & 0.7 & 1.0 & 0.3 & 0.7 & 0.8 & 1.1 & 0.3 \\
Sodium & 0.15 & 0.26 & 0.029 & 0.11 & 0.17 & 0.30 & 0.033 & 0.13 \\
Potassium & 0.031 & 0.048 & 0.045 & 0.025 & 0.034 & 0.055 & 0.051 & 0.029 \\
\hline & 0.63 & 1.2 & 0.34 & 0.35 & 0.70 & 1.37 & 0.38 & 0.41 \\
\hline
\end{tabular}

Table D.2. Physical properties.

\begin{tabular}{|c|c|c|c|c|c|c|c|c|}
\hline & \multicolumn{4}{|c|}{ MJ per $\mathrm{kg}$ fuel } & \multicolumn{4}{|c|}{ MJ per $\mathrm{kg}$ water free fuel } \\
\hline & Wheat & Barley & Willow & Giganteus & Wheat & Barley & Willow & Giganteus \\
\hline $\begin{array}{l}\text { Higher heating } \\
\text { value }\end{array}$ & 17.16 & 16.96 & 17.92 & 16.8 & 19.10 & 19.2 & 20.16 & 19.58 \\
\hline $\begin{array}{l}\text { Lower heating } \\
\text { value }\end{array}$ & 15.82 & 15.52 & 16.4 & 15.3 & & & & \\
\hline $\begin{array}{l}\text { Lower heating } \\
\text { value on water } \\
\text { free basis }\end{array}$ & & & & & 17.85 & 17.99 & 18.77 & 18.24 \\
\hline
\end{tabular}


Table D.3. Ash analysis.

\begin{tabular}{l|llll} 
& \multicolumn{4}{|c}{ w\% (water free basis) } \\
\hline & Wheat & Barley & Willow & Giganteus \\
\hline $\mathrm{SiO}_{2}$ & 62 & 22 & 15 & 39 \\
$\mathrm{Al}_{2} \mathrm{O}_{3}$ & 1.7 & 0.64 & 1.6 & 1.6 \\
$\mathrm{Fe}_{2} \mathrm{O}_{3}$ & 2.0 & 0.67 & 0.92 & 1.1 \\
$\mathrm{CaO}$ & 8.1 & 18 & 32 & 8.6 \\
$\mathrm{MgO}$ & 1.8 & 2.1 & 3.0 & 5.9 \\
$\mathrm{Na}_{2} \mathrm{O}$ & 0.36 & 1.9 & 2.6 & 2.2 \\
$\mathrm{~K}_{2} \mathrm{O}$ & 14 & 41 & 17 & 27 \\
$\mathrm{Cl}$ & 0.55 & 4.5 & 0.11 & 3.5 \\
$\mathrm{CO}_{2}$ & 0.31 & 6.2 & 18 & 0.54 \\
$\mathrm{SO}_{3}$ & 2.6 & 4.3 & 1.5 & 4.9 \\
$\mathrm{P}_{2} \mathrm{O}_{5}$ & 2.4 & 4.9 & 9.3 & 6.3 \\
\hline
\end{tabular}

The ash analyses listed in Table D.4 were based on ashes produced in the laboratory from unpyrolyzed straw in a reducing atmosphere at $500^{\circ} \mathrm{C}$.

Table D.4. Ash fusion temperatures (DS/ISO 540).

\begin{tabular}{l|ccc} 
& Deformation temperature $\left({ }^{\circ} \mathrm{C}\right)$ & Hemisphere temperature $\left({ }^{\circ} \mathrm{C}\right)$ & Flow temperature $\left({ }^{\circ} \mathrm{C}\right)$ \\
\hline Wheat & 790 & 1120 & 1320 \\
Barley & 1160 & 1230 & 1250 \\
Willow & 1110 & 1470 & 1500 \\
Giganteus & 890 & 990 & 1100 \\
\hline
\end{tabular}


Title and authors

Steam Gasification of Wheat Straw, Barley Straw, Willow and Giganteus

Lars K. Hansen, Ole Rathmann, Aksel Olsen and Karin Poulsen

\begin{tabular}{|c|c|c|c|}
\hline \multicolumn{3}{|l|}{ ISBN } & ISSN \\
\hline \multicolumn{3}{|c|}{$87-550-2247-2$} & $0106-2840$ \\
\hline \multicolumn{3}{|c|}{ Department or group } & Date \\
\hline \multicolumn{3}{|c|}{ Optics and Fluid Dynamics Department } & August 1997 \\
\hline \multicolumn{3}{|c|}{ Groups own reg. number(s) } & Project/contract No(s) \\
\hline & & & ENS-1323/95-0010 \\
\hline Pages & Tables & Illustrations & References \\
\hline 31 & 5 & 15 & 10 \\
\hline
\end{tabular}

Abstract (max. 2000 characters)

A thorough experimental study of the $\mathrm{H}_{2} \mathrm{O}$ gasification char-reactivity of wheat straw, barley straw, willow and giganteus at 1-10 bar total pressure, 0.15-1.5 bar $\mathrm{H}_{2} \mathrm{O}$ and 0 1.0 bar $\mathrm{H}_{2}$ and 750-925 C, was performed in a Pressurized Thermogravimetric Analyzer. There were a total of 58 experiments.

Kinetic experiments with char of wheat straw at 10 bar total pressure showed that the reactivity increases with rising temperature and increasing partial pressure of $\mathrm{H}_{2} \mathrm{O}$, while it decreases with increasing partial pressure of $\mathrm{H}_{2}$. At constant partial $\mathrm{H}_{2} \mathrm{O}$ pressure in the absence of $\mathrm{H}_{2}$, an indication of a negative influence by the total pressure was observed.

Except for the effect of total pressure, the experimental data were analyzed by means of the Langmuir-Hinshelwood equation, including both inhibition by $\mathrm{H}_{2}$ and reactivity limitation at high $\mathrm{H}_{2} \mathrm{O}$ concentration. Also, the reactivity profile was assumed to be independent of temperature and reactant concentration. The value found for the main activation energy $E_{1}, 149 \mathrm{~kJ} / \mathrm{mole}$, describing the temperature dependence at low $\mathrm{H}_{2} \mathrm{O}$ concentration, is close to experimental values for biomass reported by other workers. At conditions relevant to both fluid-bed and entrained-flow gasifier types the present results indicate an inhibiting effect of the product gas $\mathrm{H}_{2}$, reducing the reactivity by a factor of up to 10.

A screening study of steam gasification of barley straw, willow and giganteus in addition to the wheat straw showed reaction rates with rather equal temperature dependence. However, at equal temperatures, there was a spread in reactivity of about 10 times from the lowest (wheat and giganteus) to the highest (barley), probably due to different contents of catalytic elements.

The project has been carried out under the EFP-95 programme for the Danish Ministry of Environment and Energy and for the Danish utility associations Elsam and Elkraft.

Descriptors INIS/EDB

Available on request from Information Service Department, Risø National Laboratory, (Afdelingen for Informationsservice, Forskningscenter Ris $\varnothing$ ), P.O.Box 49, DK-4000 Roskilde, Denmark. Telephone +4546774004 , Telefax +4546774013 